New Information on the Degree of "Sinicization" of the Tuyuhun Clan during Tang Times through Their Marriage Alliances: A Case Study Based on the Epitaphs of Two Chinese Princesses

Escher, Julia Barbara

Posted at the Zurich Open Repository and Archive, University of Zurich

ZORA URL: https://doi.org/10.5167/uzh-181630

Journal Article

Published Version

Originally published at:

Escher, Julia Barbara (2019). New Information on the Degree of "Sinicization" of the Tuyuhun Clan during Tang Times through Their Marriage Alliances: A Case Study Based on the Epitaphs of Two Chinese Princesses. Journal of Asian History, 53(1):55-96. 


\section{OFFPRINT FROM:}

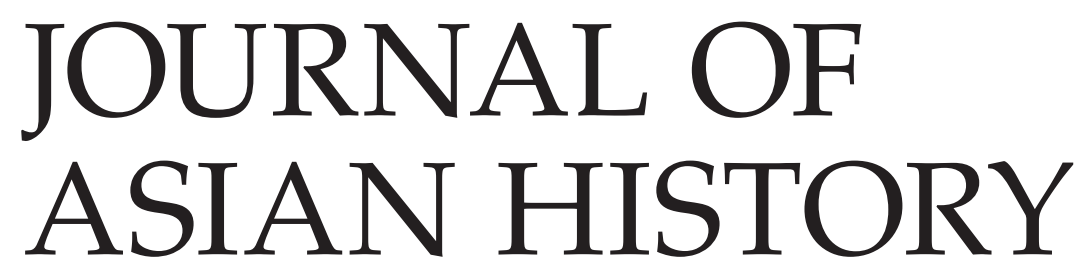

EDITED BY

Dorothee SchaAb-Hanke and Achim Mittag

$53(2019) 1$

Harrassowitz Verlag • Wiesbaden 
Editors / Contact:

Dorothee Schaab-Hanke (Großheirath): DSchaab-Hanke@t-online.de

Achim Mittag (Tübingen): achim.mittag@uni-tuebingen.de

International Advisory Board:

Prof. Dr. Wolfgang Behr (Zuerich), Prof. Dr. Timothy Brook (British Columbia),

Prof. Dr. Christopher Cullen (Cambridge), Prof. Dr. Roderich Ptak (Munich),

Prof. Dr. Nicolas Standaert (Leuven), Prof. Dr. Barend Jan Terwiel (Hamburg)

The Journal of Asian History is a refereed journal.

\section{Zugang zur elektronischen Version / Access to electronic format}

Diese Zeitschrift kann auch in elektronischer Form über JSTOR (www.jstor.org) bezogen werden.

This journal can also be accessed electronically via JSTOR (www.jstor.org).

(c) Otto Harrassowitz GmbH \& Co. KG, Wiesbaden 2019

This journal, including all of its parts, is protected by copyright. Any use beyond the limits of copyright law without the permission of the publisher is forbidden and subject to penalty. This applies particularly to reproductions, translations, microfilms and storage and processing in electronic systems.

Copyediting and phototypesetting: Martin Hanke, Großheirath

Language editing: Markus Conley

Printing and binding by Hubert \& Co., Göttingen

Printed on permanent / durable paper

Printed in Germany

www.harrassowitz-verlag.de

ISSN 0021-910X 


\section{Contents}

\section{Articles}

ZHANG Zhaoyang 張朝陽 and YAN Lin 閏璘, How to Enter a Palace Legally:

Information Gained from Newly Excavated Han Documents

Michael LOEWE, Consultants and Advisors, and the Tests of Talent

in Western and Eastern Han

Julia ESCHER, New Information on the Degree of "Sinicization" of the Tuyuhun Clan during Tang Times through Their Marriage Alliances:

A Case Study Based on the Epitaphs of Two Chinese Princesses

JoO Hyun-ho 주현호, Under the Censor's Gaze:

The Dong-A Daily's Presentation of Sun Yat-sen in the Early 1920s

\section{Discussion Forum}

\section{[TayJEONG. The Politics of Historical Knowledge ( $A$ AH 52.1)]}

A Note from the Editors

Andrew LOGIE, The Politics of Feigned Impartiality

The Debate on the Historical Geography of Old Chosŏn and Lelang Commandery ... 117

\section{Reviews of Books}

Luís Filipe Barreto and Wu Zhiliang [吴志良] (eds.).

Travels and Knowledge (China, Macau and Global Connections) (Roderich Ptak) 151

Zhou Weimin 周伟民 and Tang Lingling 唐玲玲. Hainan tongshi: Mingdai juan

海南通史一明代卷 (Roderich Ptak)

Martin Gimm. Der geheime Schamanismus der Qing-Kaiser

und der Schamanentempel Tangzi in Beijing (Hartmut Walravens)

Jonathan Schlesinger. A World Trimmed with Fur:

Wild Things, Pristine Places, and the Natural Fringes of Qing Rule (Fei Huang)

Harald Meyer, Christine Schirrmacher und Ulrich Vollmer (Hg.).

Die Bonner Orient-und Asienwissenschaften. Eine Geschichte in 22 Porträts (Hartmut Walravens) 



\title{
New Information on the Degree of "Sinicization" of the Tuyuhun Clan during Tang Times through Their Marriage Alliances: A Case Study Based on the Epitaphs of Two Chinese Princesses
}

\author{
Julia Escher*
}

\section{Introduction}

Throughout the history of imperial China, we can find records of marriage alliances between Chinese dynasties and foreign powers. In many cases, the Chinese gave a princess of imperial kinship, but not the actual daughter, as a wife to the foreign ruler. This paper presents the marriage alliances concluded between Chinese dynasties and the Tuyuhun 吐谷渾 kingdom and illustrates how they mirror the political position of the Tuyuhun. The Tuyuhun controlled parts of the trade routes that connected China to Central Asia and beyond, which allowed them to play a key role in the trade between various states as well as in their cultural exchange and the spread of religious ideas. Their state reached its peak in the first half of the 7th century when, even though they lacked the militarily strength of Tibet or the Turks, they were an important player in the power struggle between these powers and the Tang 唐 (618907) dynasty. This study will be based mainly on two epitaphs written for Chinese princesses, which, along with several epitaphs for members of the Tuyuhun ruling clan, were unearthed at Wuwei 武威, Gansu 甘肅, in 1945 by the renowned Chinese archaeologists Xia Nai 夏鼎 (1910-1985) and Yan Wenru 阎文儒 (1912-1994). ${ }^{1}$ These inscriptions are not only very valuable for the study of the relations between the Tuyuhun and Tang, but also for understanding the Tuyuhun elite in general. To my knowledge, none of these epitaphs have yet been translated into any Western language. Needless to say, a translation of all the epitaphs of the royal clan would be of great interest to the study of the Tuyuhun, but this paper will focus on the inscriptions written for the two princesses. An analysis of the marriage alliances concluded between the Tang and Tuyuhun will show that parts of the Tuyuhun ruling house became

\footnotetext{
* Julia Escher is a research assistant and PhD student at the Asien-Orient-Institut of the University of Zurich. She is mainly working on marital politics between Chinese dynasties and other states in early medieval China. Her other research interests include questions of ethnicity and ethnic identity, as well as material and visual culture of (early) medieval China. She may be reached at julia.escher@uzh.ch.

1 Xia 2011; Xia 2002.
}

Journal of Asian History 53.1 (2019) 
increasingly Sinicized due to intermarriage. This development can also be observed in the epitaphs of this family. However, even though the epitaphs show a strong adherence to the Chinese epitaph tradition, they should not be read as a sign of an on-going process of Sinicization of the entire Tuyuhun elite, and especially not of the entire Tuyhun population as an "ethnic group". These epitaphs only reflect the active participation of one branch of the Tuyuhun elite in marital politics with the Tang and the resulting Sinicization of this particular family.

\section{Who Were the Tuyuhun?}

Murong Tuyuhun 慕容吐谷渾 (245-317), the founding figure of the Tuyuhun kingdom, and his descendants were of Murong 慕容 ${ }^{2}$ ethnic origin. The Murong were a branch of the Xianbei 鮮卑, a seminomadic people who originally settled in southern Manchuria. ${ }^{3} \mathrm{Mu}$ rong Tuyuhun and his followers had migrated westwards and arrived in the area around

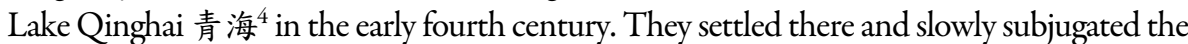
local tribes under Murong Tuyuhun's rule. Therefore, the people of the Tuyuhun were ethnically quite diverse. Apart from the Murong people, the Qiang 姜 and Di 氏, ${ }^{5}$ also lived in this new realm. It is thus not easy to discern at what point we can speak of the "Tuyuhun" as an ethnically unified group, if at all. When approaching this subject, one should bear in mind that identities were very fluid constructs at that time and ethnic origins may not necessarily have been reflected in identity constructions or cultural identification. We can assume that the various ethnic groups existing in the Tuyuhun state in the early fourth century slowly merged over the centuries, but people belonging to other ethnic groups from China, the Western Regions or Central Asia also passed through the Tuyuhun territory and some of them stayed there. These people most certainly exerted their respective influences within the Tuyuhun realm when participating in the local life as well. Thus, the "ethnicity" of any given region was very much a loose idea during this period, especially in a cultural melting-pot like the Tuyuhun territories. When we speak of "the Tuyuhun", we should therefore not think

2 In Pulleyblank 1991, 220, 267, Murong is reconstructed as EMC (Early Middle Chinese) ${ }^{*} \mathrm{~m}^{\mathrm{h}}$-juawn.

3 EMC*sian'-pji/pjiě; see Pulleyblank 1991,31,396. The Xianbei can be divided into two main branches, the more well-known of the two being the Tuoba 拓拔 (EMC * $\mathrm{t}^{\mathrm{h}}$ ak-bait/be:t, Pulleyblank 1991, 27,314), who later founded the Northern Wei 魏 dynasty (386-535). The Murong Xianbei also successively founded several states during the early fourth century: the Former Yan 燕 (337-370), Western Yan (384-394), Later Yan (384-409), and Southern Yan (398-410) dynasties. For an overview over the Xianbei, see Holcombe 2013.

4 Also known in Mongolian as Koko-nor; located in modern-day Qinghai Province.

5 Chen Sanping 2012, 79; Pan 1997b, 45. On the Qiang (EMC khian, Pulleyblank 1991, 251) and Di (EMC*tej, Pulleyblank 1991,74) see also Ma 2006. 
of one ethnically homogenous entity, but of the entirety of ethnically different people living in the area. The Tuyuhun state clearly comprised various languages, cultural backgrounds and ethnic groups.

Due to the scarcity of transmitted linguistic material, we can only make learned guesses when it comes to the exact nature of the language spoken by the Tuyuhun Murong elite. An in-depth discussion of this matter would certainly go beyond the scope of this paper. Pelliot already noted that they, being of Xianbei origin, most probably spoke the same language as other Xianbei peoples, which he identified as a Mongolic language. ${ }^{6}$ Today it is thought that the Xianbei/Tuyuhun language was some form of Para-Mongolic, to be understood as a sister node of Mongolic in the reconstructed ancestral Xianbei-Mongolic language tree.

Over the centuries, the term "Tuyuhun" was used to refer to many different things. Originally the name of a person, it was later used as the clan name of the ruling house by Tuyuhun's grandson Sheyan 葉延 (r. 329-351), as well as the designation for the newlyfounded Tuyuhun state. The Liang shu 梁書 (Book of Liang) tells us that these renamings were connected to ancient Chinese ritual practices. According to these practices, the grandson establishes the grandfather's name as the new clan name of the ruling lineage as well as the name of the state. ${ }^{8}$ Later on, the term was also used as a reference to the people living in this state, often implying some sort of ethnic unity as "the Tuyuhun people", even if such an ethnically unified group did not exist. Today, it is still very common for the term "Tuyuhun" to be understood in this sense.?

The people living in the Tuyuhun kingdom were mainly seminomads. Their administration was based on the Chinese model, and they also used Chinese script as their writing system. ${ }^{10}$ They were well known for breeding fine horses. One of their leaders, Kualü 夸呂 (r. 540-591), is described as sitting on a golden bed in the shape of a lion. Interestingly, the king of Kucha ${ }^{11}$ as well as the Hephthalite king ${ }^{12}$ also used a golden lion bed as a throne. Moreover, we know of several depictions of the Buddha seated on a lion throne that have been found in Gansu Province, ${ }^{13}$ and it is attested in transmitted texts that the Tuyuhun elite were followers

6 Pelliot 1920, 326-330.

7 Vovin 2015, Shimunek 2017.

8 Liangshu 54.810.

9 See for example Yu 2013, Li Zhanzhong 2003, Li Li 2010.

10 Pan 1997b, 45.

11 Molè 1970, 113. She cites Wei shu魏書 (Book of Wei) 102.2266.

12 Liang shu 54.812. The Hephtalites were a Central Asian people who, during the 5th and 6th centuries, extended their power to Kucha, Khotan, and even the Turfan region. See also Litvinsky et al. 1996; de la Vaissière 2003.

13 See also Rhie 2010,36-38. 
of Buddhism. ${ }^{14}$ Based on these observations, we can see that a lively exchange with other cultures most definitely also influenced the material culture and religious life in the Tuyuhun kingdom.

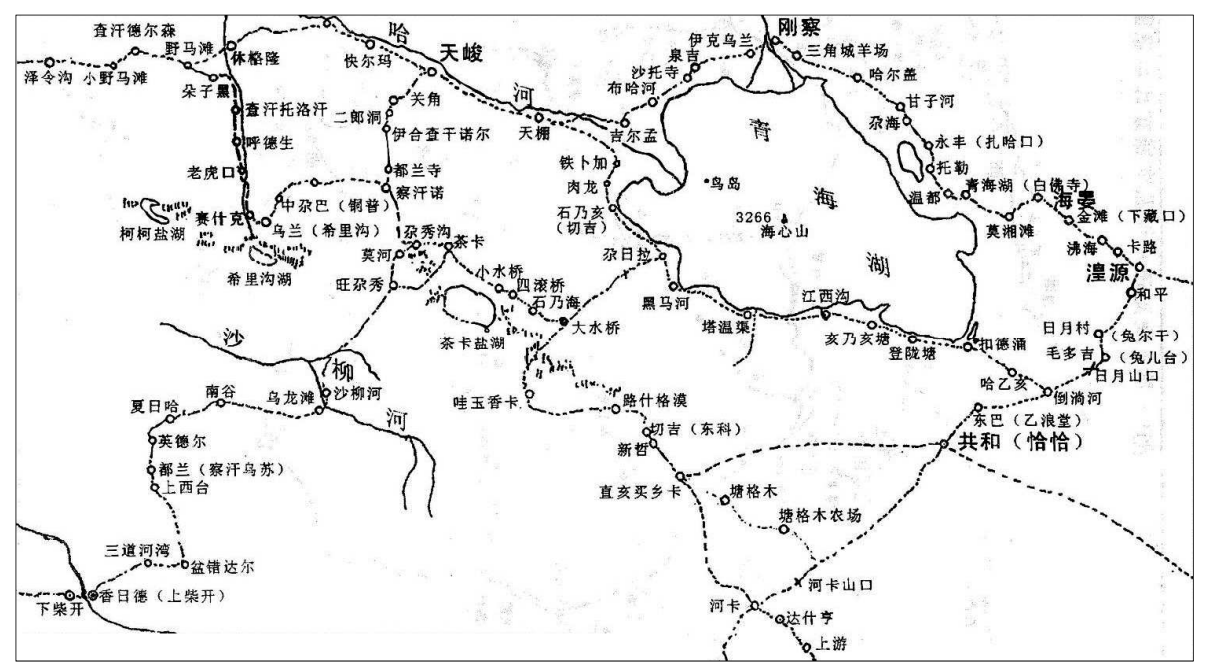

Ill. 1: Map of the Trade Routes around Lake Qinghai (Chen Liangwei 2002, 138)

By the time of the Northern and Southern dynasties, a network of trade routes had slowly developed into what would later be termed the Silk Road. ${ }^{15}$ A branch of these routes, known as the Henan 河南 route, ran through Tuyuhun territory (for a map of the trade routes around Lake Qinghai, see ill. 1). The Tuyuhun were therefore becoming increasingly important in the commercial, cultural, and religious exchange between Central Asia, the oasis states in the Tarim Basin, the Mongolian steppes, and the various Chinese dynasties. Sometimes, valuable goods such as textiles and lacquerware, but also pelts and exotic animals, were brought to the Chinese cities via these routes. ${ }^{16}$ Tribute and trade missions as well as monks and envoys used the Tuyuhun routes for their travels to other states. The Tuyuhun themselves also dispatched missions to the Southern courts, with which they maintained close

14 Liangshu 54.810.

15 See Hansen 2012, 5-8, on the concept of a "Silk Road", which entailed much more than trade, but also "transmitted ideas, technologies, and artistic motifs."

16 Chen Liangwei 2002, 295. The Liang shu (54.812) mentions a tribute mission the Hephtalites sent to the Liang court in 520, which came bearing exotic gifts such as lions, pelts, and Persian silk. According to Lung 2011, 33, on one occasion the Tuyuhun led a trade mission with 240 non-Chinese traders, 600 camels and donkeys, and tens of thousands of rolls of silk fabric to the Northern Wei capital. 
relations. They were never at war with any of the Southern dynasties, and accepted the titles they bestowed on them, which formally made them their subjects. The Southern dynasties in turn hoped for support from the Tuyuhun in their conflict with the Northern dynasties, especially the Northern Wei. The Tuyuhun's relationship with the Northern states, on the other hand, was characterized by recurring conflicts and skirmishes along the borders.

In addition to guiding trade and tribute missions through their lands or to foreign courts, the Tuyuhun might also have taken on the role of interpreters and acted as translators of written documents for the Chinese courts. Lung states that they probably scripted official letters for the Chinese courts in cases where the non-Chinese members of tribute or trade missions were not familiar with the Chinese writing system and rhetoric. ${ }^{17} \mathrm{~A}$ state which most certainly relied on Tuyuhun assistance in communicating with the Chinese courts was the one ruled by the Hephthalites. According to the Liang shu, they had to rely on conquered states for administration, because they themselves did not have a script. It further states: "Their [spoken] language needs to be translated by someone from Henan, before it can be understood [in the Liang state]" ${ }^{18}$ "The people from Henan" was an alternative designation for the Tuyuhun, who were apparently able to understand the language spoken by the Hephthalites and acted as translators and interpreters. ${ }^{19}$

\section{Marriage Alliances as a Diplomatic Tool}

Marital politics was part of an array of diplomatic tools, which also included tributes, the exchange of gifts, envoys, hostages, and the bestowal of titles. ${ }^{20}$ The use of marriage alliances with other parties by sending a Chinese bride to a foreign ruler is generally called heqin 和親, a term which goes back to the first marriage alliance between Han Emperor Gaozu 高祖 (r. 202 BC195 BC) and the Xiongnu 匈奴 ruler Modun 莫頓. ${ }^{21}$ The goal of heqin was the establish-

17 Lung 2011,31-32. See also Liang shu 54.810.

18 Liang shu 54.812. The exact nature of the language used by the Hephtalites is still subject to discussion among scholars, although the general consesus is that the Hephtalites used an Iranian language (e.g. Tremblay 2001, 186). Shimunek $(2017,57)$, however, thinks that they spoke an early Serbi-Mongolic language.

19 Lung 2011, 32. The Hephtalites undertook five missions to the Liang court, in 516, 520, 526, 535, and 541, possibly with Tuyuhun support; see Chen Liangwei 2002, 295-296.

20 On marriage alliances throughout Chinese history, see Pan 1997a and Holmgren 1990. Selbitschka 2015, 73-77 and Thatcher 1991 provide an analysis of marriage alliances in Spring and Autumn diplomacy. A thorough discussion of diplomacy in early imperial China can be found in Selbitschka (2015). Pan (1997 (2)) gives a general overview of Chinese foreign policy from the Han to the Tang with a focus on SuiTang.

21 Han shu 漢書 (Book of Han) 43.2122. See also the discussion in section 3. 
ment of peaceful relations with a foreign entity through the creation of kinship by means of marriage. However, several scholars point out that the heqin policy of Han times in fact also encompassed several other elements of foreign policy. ${ }^{22}$ In the case of the first heqin alliance, the Chinese also made annual payments of various goods and foodstuffs to the Xiongnu, the Han and the Xiongnu were to be "brotherly" states, the border markets were to be opened, and the Great Wall was designated the border between the Han and the Xiongnu. ${ }^{23}$ These requirements are however very specific to the heqin alliances concluded with the Xiongnu. Records of later cases indicate that the concluded alliances did not necessarily entail all the abovementioned elements. Regular Chinese payments for instance do not seem to have been common in later marriage alliances. Moreover, the transmitted sources usually do not make use of the term heqin when recording these marriages. In the text passages describing the marriage alliances concluded with Tuyuhun rulers, the term does not appear at all. ${ }^{24}$ In addition, in each case the passages mention that the Tuyuhun made regular payments of tribute to the Chinese court after the marriage was concluded, which contradicts the original description of beqin in two ways. Firstly, the payments went in the other direction, from the recipient of the bride, i.e. the Tuyuhun, to the Chinese. Secondly, the act of paying tribute ${ }^{25}$ implied a certain recognition of Chinese superiority, thereby contradicting the brotherly and equal relationship that was to be concluded in the first heqin alliances with the Xiongnu. This observation indicates that the measures described in the original heqin policy with respect to the Xiongnu are not necessarily applicable to other marriage alliances and that in reality marital politics was probably more flexible, depending on the political circumstances at hand. A more pragmatic approach to marriage alliances existed than what the idealized system of heqin leads us to believe, and many different parties participated in this strategy. We should therefore keep in mind that, while it is certainly helpful to have a solid understanding of the origins of heqin and what it initially entailed, the political landscape changed considerably over the centuries to

22 Pan 1997b, 29; Selbitschka 2015, 65; Chin 2010, 338.

23 Han shu 94A.3756; Shiji 史記 (Records of the Grand Historian) 110.2895; Pan 1997b, 29; Chin 2010, 338.

24 Bei shi 北史 (History of the Northern Dynasties) 96.3186-87; Sui shu 隋書 (Book of Sui).1844; Xin Tang shu 新唐書 (New Book of Tang) 221A.6226-27; Jiu Tang shu 舊唐書 (Old Book of Tang) 198.5300 .

25 See also Selbitschka 2015 for a thorough discussion of the concept of a tributary system. He convincingly argues against a distinction between heqin and the tributary system, which, in his view, were not separate systems of policies, but rather both integral parts of early Chinese diplomacy. The fact that regular payments of tribute are often mentioned after the record of a marriage alliance shows that these were closely connected and may be understood as two elements of the same strategy. 
follow, and the conditions of later marriage alliances did not fit into this Xiongnu-specific blueprint of heqin. ${ }^{26}$

It is sometimes postulated that the power on the receiving end, in our study the Tuyuhun, was mainly motivated by material considerations. ${ }^{27}$ Jagchid and van Simons suggest that Chinese princesses were merely viewed as another form of chattel and that foreign states were mostly interested in marriage alliances because of the material gain, such as dowries and wedding gifts. ${ }^{28}$ In their view, one side consisted of a nomadic group that was simply interested in gaining access to Chinese wealth, while the other side consisted of the courts of the agrarian Chinese, which were only motivated by ideology and strategy. We cannot deny that political and ideological considerations played an important role in the Chinese strategy of marriage alliances and that there was often a considerable amount of wealth and prestige to be gained from such marriages. Still, this approach seems somewhat oversimplified, especially in view of the fact that it covers a large number of marriage alliances, spread over several centuries, involving various different parties and rulers. Moreover, the nomadic powers - to use Jagchid and van Simons' term - also intermarried with each other. Thus, the diplomatic aspect of marital politics was probably at least as important for these states as the material gain. Even though the foreign power did indeed usually receive a dowry and wedding gifts, it often also presented a considerable amount of gifts when asking for a princess and regularly paid tribute after the marriage was concluded. ${ }^{29}$ Furthermore, a marriage alliance could sometimes also result in military assistance if needed. It is therefore necessary to rethink this dichotomy of non-Han vs. Han and sedentary Chinese vs. (semi-) nomadic "barbarians" 30 and to examine how this rigid categorization is really reflected in the multifaceted reality of early medieval China and its marital politics. With regard to the so-called tributary system, Selbitschka very accurately points out that it is often assumed that the Chinese were simply reacting to barbarian demands, and that no differentiation between various ethnic groups took place. ${ }^{31}$ In my view, this statement also applies to the study of marital politics, as marriage alliances are often perceived as a typical strategy of nomadic powers. ${ }^{32}$ Even though marriage alliances may have been common between different groups with a nomadic cultural background, the Chinese dynasties also participated in this practice over the centuries. Let us also keep in mind that

26 On that note, see also Selbitschka 2015, 70, 114.

27 Holmgren 1990, 59-60.

28 Jagchid and van Simons 1989, 141.

29 See for example the case of Princess Honghua, which is discussed in section 4.3.1.

30 E.g. Zhou 1988, 14; Pan 1997b, 100; Holmgren 1990, 59.

31 Selbitschka 2015, 64.

32 Pan 1997b, 100. 
marriage among influential families was an important element of Chinese society throughout its history (and in numerous other societies for that matter). In what way, then, is it advisable to label the diplomatic tool of marriage alliance as a typically non-Chinese practice or as an integral part of nomadic tradition?

\section{The Meaning of "Princess" and the Role of Kinship}

At first glance, the meaning of the term “princess" (gongzhu 公主) might seem quite straightforward: A princess is a daughter of an emperor or a king. But in imperial China, this term was also used in a somewhat broader sense; it was also a title which could be bestowed upon any female subject of the realm. Sources dating to the Tang dynasty show that the title of a princess could be modified with a variety of prefixes in accordance with her (sometimes constructed) degree of kinship to the emperor and the overall status of her family. Early forms of these different titles for princesses already existed in Han times. In the passage describing the first heqin alliance, ${ }^{33}$ we find different designations for princesses: The emperor's own daughter is referred to as "Elder Princess" (zhang gongzhu 長公主); the daughter of a commoner who is given to the Xiongnu is simply called "Princess". The investment of princess titles for symbolic reasons continued after the end of the Han. ${ }^{34}$ By the time of the Tang dynasty, the ranks of the different princess titles and the size of their enfeoffments were already defined quite clearly: ${ }^{35}$

\begin{tabular}{|l|l|l|l|}
\hline Princess Title & Kinship to Emperor & Rank & Fiefdom \\
\hline Grand Elder Princess 大長公主 & paternal aunt & First Zheng & kingdom \\
\hline Elder Princess 長公主 & sister, occasionally eldest or favorite daughter & First Zheng & kingdom \\
\hline Princess 公主 & daughter & First Zheng & kingdom \\
\hline Commandery Princess 郡主 & daughter of the heir apparent & First Cong & commandery \\
\hline District Princess 縣主 & $\begin{array}{l}\text { daughter of an emperor's brother or son, } \\
\text { daughter of a king }\end{array}$ & Second Zheng & district \\
\hline
\end{tabular}

Table 1: Ranks of Princess Titles as Formulated in the Tongdian

In the Tang huiyao 唐會要 (Dynastic Records of the Tang) we find further elaborations on the different names used in the various types of titles. These names usually designated the territories with which the princesses were enfeoffed, the typical pattern being: [princess title + name of fiefdom]. Sometimes the title would include an attribute rather than a toponym,

33 Han shu 43.2122.

34 See for example the record of the Eastern Wei princess Guangle 廣樂, who was wed to the Tuyuhun ruler Kualü; see Bei shi 96.3186-3187; also discussed in section 4.1.

35 The information given in the following table is based on Tongdian 通典 31.869-870 and Hucker 1985. 
common examples being “great peace” (taiping 太平), “peaceful joy” (anle 安樂) or “eternal tranquility” (changning 長寧). ${ }^{36}$ Furthermore, the Tang huiyao contains a short list of women who were given as brides to foreign rulers (hefan gongzhu 和蕃公主 "princesses of making peace with foreigners"). Princess Honghua 弘化, wife of the Tuyuhun ruler Nuohebo 慕 蓉諾曷鉢 (r. 635-672), appears first on this list. However, the entries for these princesses usually provide no more information than the date of marriage and the name of the husband. We should also bear in mind that rules described in the Tang huiyao were formulated during the Tang dynasty and do not apply to earlier cases of investments of princess titles.

The investment of unrelated women or girls with princess titles probably had its beginnings in the first heqin marriage between a Chinese daughter of the royal house and the Xiongnu leader Modun in 198 BC. In the Han shu, it is recorded that the advisor Lou Jing 婁敬 first suggested sending the real daughter of Emperor Gaozu to the Xiongnu. But the empress objected to abandoning their daughter. It was decided to take a daughter of a commoner, to give her the title of princess, and to send her instead. ${ }^{37}$ As Selbitschka ${ }^{38}$ has pointed out in his discussion of marital politics in pre-imperial China, "The daughters of the rulers served the double purpose of assuring peaceful relations on account of their close bonds to their birth families and because they assumed a role comparable to hostages. If anything went wrong between the participating parties, the lives of the women could have been used for leverage." If it became apparent to the foreign party that the bride was not an imperial daughter and of no actual relevance to the Chinese court, they might not have felt obliged to accord respect to the Chinese bride, or to adhere to the alliance. The bestowal of a princess title was therefore a crucial part of the marital strategy that served to maintain the illusion that the involved bride was an actual daughter of the emperor. However, the other parties certainly realized quickly that these women or girls were often not princesses by blood but only by title. Nevertheless, it seems that in most cases the prestige of a princess title still sufficed for the marriage alliance to be upheld. ${ }^{39}$

The marriage alliance proposed by Lou Jing is generally regarded as the beginning of the implementation of heqin policy by Chinese rulers, with the aim of establishing peaceful relations through kinship. In order for this strategy to work, it was paramount that the woman be (at least nominally) a princess. If the goal was to establish a relation through kinship, it was

36 Tang huiyao 6.63.

37 Han shu 43.2122.

38 Selbitschka 2015,75.

39 It was revealed at one point to the Tuyuhun, that the Chinese princess Honghua was not a real daughter of the emperor; see Jiu Tang shu 198.5300, 60.2354; Xin Tang shu 221A.622. However, this incident apparently did not affect the alliance. 
of course necessary that bride-to-be be related to the emperor, even if this was only a fabricated connection. Moreover, by sending women or girls that nominally belonged to the lineage of the emperor, the Chinese often also transferred their expectations of the proper behavior of a superior family member onto the foreign party. According to the Chinese understanding of kinship propriety, Modun, by marrying a Chinese princess, would become Emperor Gaozu's son-in-law and therefore be subordinate to the Han ruler. Moreover, a possible son from this marriage and future ruler of the Xiongnu was expected to pay respect to his grandfather, the Han emperor. ${ }^{40}$ Even though Lou Jing's plan did not manifest itself in the way he had imagined, it illustrates the expectations the Chinese had for the heqin policy and how closely these were connected to kinship propriety. As Tamara Chin has described accurately:

Ritually correct, procreative marriage will reverse Han-Xiongnu power relations "without a battle." 41

Still, it remains to be said that, although this was the first case in which such a policy was termed heqin, kinship was already a key element in the diplomatic value of marriage alliances before the term heqin was coined at the Han court, as Selbitschka ${ }^{42}$ has shown convincingly in his analysis, and it remained important for later marriage alliances.

\section{Marriage Alliances between the Tuyuhun and Chinese Dynasties}

The records transmitted in the dynastic histories describe five cases of marriage alliances between the imperial house of a Chinese dynasty and the Tuyuhun ruling clan between the mid-6th and the mid-7th centuries (see table 2). ${ }^{43}$

\begin{tabular}{|l|l|l|}
\hline Year & Groom & Bride \\
\hline c. 540 & Emperor Xiaojing of Eastern Wei & a cousin of the Tuyuhun ruler Kualü \\
\hline c. 540 & Tuyuhun ruler Kualü & Princess Guangle of Eastern Wei \\
\hline 596 & Tuyuhun ruler Fu & Princess Guanghua of Sui \\
\hline 597 & Tuyuhun ruler Fuyun & Princess Guanghua of Sui \\
\hline 640 & Tuyuhun ruler Nuohebo & Princess Honghua of Tang \\
\hline c. 652 & eldest son of Nuohebo & Princess Jincheng of Tang \\
\hline between 652 and 659 & second son of Nuohebo & Princess Jinming of Tang \\
\hline
\end{tabular}

Table 2: Marriage Alliances Concluded between Tuyuhun and Chinese Rulers

40 Han shu 43.2122.

41 Chin 2010,341.

42 Selbitschka 2015,77.

43 The two marriages around 540 are counted as one case, since they were concluded at the same time and formed part of the same alliance. Princess Guanghua's marriage to Fuyun shortly after her first husband's death is seen as a continuation or renewal of the alliance. 
None of the cases were recorded as heqin, which indicates that the marriages were perceived as pragmatic reactions to political circumstances and not as adherence to a heqin "system". After a short description of the cases of Princess Guangle of Eastern Wei and Princess Guanghua 光化 of Sui, this paper will focus on the alliances concluded between the Tuyuhun and the Tang dynasty. The repeated intermarriage reflected in these marriages probably led to an increased influence of Chinese culture on this family, which was originally of Murong Xianbei descent. The Sinicization of this branch of the Tuyuhun ruling house is clearly seen in the epitaphs dedicated to two Chinese princesses, which will be discussed in sections 4.3.1 and 4.3.2.

\subsection{Eastern Wei}

The period of the Northern and Southern dynasties was characterized by the various newly established dynasties, which all tried to strengthen their states and were often reliant on alliances with other rulers in order to gain access to military support against an enemy or used the prestige of an alliance to strengthen the legitimacy of their rulership among their own subjects. Several marriage alliances are recorded for this period, mostly among the Northern states. ${ }^{44}$ The women that were married off were frequently sisters or daughters of the rulers and the marriages were often conducted as between equals. ${ }^{45}$ The political landscape became even more fragmented after the fall of the Northern Wei dynasty and the establishment of the Eastern Wei 東魏 (534-550) and Western Wei 西魏 (535-556). These two dynasties and the (at that time) powerful Rouran 柔然 ${ }^{46}$ to the north formed a power triangle, in which the Eastern and Western Wei competed for the Rouran's favor by concluding marriage alliances. ${ }^{47}$ In this setting, the Eastern Wei conducted two marriages with the Tuyuhun: Kualü offered his cousin to the Eastern Wei emperor Xiaojing 孝靜 (r. 534-550) and received Princess Guangle from the Eastern Wei as a wife around $540 .{ }^{48}$ The Tuyuhun were often in conflict with their neighbor, the Western Wei. ${ }^{49}$ It therefore seems plausible that the Eastern Wei and the Tuyuhun sought to strengthen their ties through marriage alliances, in a common effort to weaken or even fight their Western Wei rival. It might not be entirely insignifi-

44 For a short overview of marriage alliances concluded in this time period, see Pan 1997a, 103-108.

45 Pan 1997a, 104.

46 The Rouran were a nomadic confederation located on the northern edge of Chinese territory, in what is today known as Mongolia. For an introduction to the Rouran, see also Kradin 2005.

47 Pan 1997a, 107; Bei shi 13.506-507, 98.3264-3265.

48 We learn from Bei shi 96. 3186-3187 that she was a granddaughter of a certain King Kuang 匤 of Jinan 濟南.

49 See for example Bei shi 96.3187. 
cant that for a while the Western Wei had an empress of Tuyuhun origin, Empress Yifu 乙弗, whose ancestors had previously submitted to the Western Wei dynasty. The Bei shi records that Empress Yifu did not come from just any Tuyuhun family but was the descendant of a Tuyuhun leader. ${ }^{50}$ The name of this ancestor is, however, not mentioned. When the Western Wei and the Rouran decided upon a marriage alliance, the Rouran leader Anagui 阿那瓖 (r. 520-552) demanded that the Tuyuhun empress be dismissed and that his daughter be made empress. In 540, the former empress, Yifu, was forced to commit suicide. ${ }^{51}$ Interestingly, the forced suicide of Empress Yifu took place in the same year the Tuyuhun decided to conclude an alliance with the Eastern Wei. Thus, the alliance between the Tuyuhun and the Eastern Wei may have been a reaction to the dismissal and forced suicide of Empress Yifu. There is probably more to these incidents than meets the eye, and further study of these marriages might shed more light on this matter.

\subsection{Sui}

During the Sui dynasty, the absolute number of princesses married to foreign leaders was relatively small, but considering the short lifespan of the dynasty, the Sui court was still rather active in forging marriage alliances. Holmgren observes that during the almost 37 years of Sui rule, six marriage alliances were conducted, i.e. an average of one marriage every six years. By comparison, the Tang dynasty, which sent the most princesses in absolute numbers (at least 20 ), forged on average one marriage alliance every 14.5 years. ${ }^{52}$ Sui's relatively heavy involvement in marriage alliances was probably due to the fact that the newly founded dynasty had to establish good relations with the other powers in order to survive.

In contrast to the earlier dynasties, the Sui did not accept women from other states into the imperial harem. ${ }^{53}$ Instead, the marriage alliance took the form of a Chinese princess being married to a foreign leader. The Tang dynasty would later continue to hold on to this principle. ${ }^{54}$ For this reason, Emperor Wen 文 of Sui (r. 581-604) refused when the Tuyuhun ruler $\mathrm{Fu}$ 伏 (r. 591-597) sent a mission to the Sui court in 591 suggesting to marry a Tuyuhun woman to the emperor. ${ }^{55}$ In 596, Emperor Wen gave Princess Guanghua 光化 to Fu as a

50 Beishi 13.506-507.

51 Zizhi tongjian 資治通監 (Comprehensive Mirror in Aid of Governance) 158.4892. See also Pan 1997a, 107.

52 Holmgren 1990, 36.

53 Pan 1997a, 109.

54 Pan 1997a, 124.

55 Sui shu 83.1844. A similar passage divided into two parts can be found in the Zizhi tongjian. In these passages, Fu is called Shifu 世伏; see Zizhi tongiian 178.5551, 5560. 
wife, thus forming a marriage alliance with the Tuyuhun. ${ }^{56} \mathrm{Fu}$ was killed in the following year during internal power struggles, and because the Tuyuhun followed the practice of levirate marriage, Fu's younger brother Fuyun 伏允 (r. 597-635) married Princess Guanghua. Fuyun later had to flee because he was attacked by Sui troops, and Princess Guanghua was taken hostage. ${ }^{57}$ No further details are known concerning her origin, year of birth or death, or the location of her tomb. We can only guess why the emperor decided to agree to a marriage alliance in 596, as he had not shown much concern for Tuyuhun affairs before. His strongest rival at the time was the Western Turks. Emperor Wen probably wanted to maintain amicable diplomatic relations with their opponents, mainly the Eastern Turks. The fact that their qaghan had a Tuyuhun wife ${ }^{58}$ shows that the Eastern Turks and the Tuyuhun had previously forged a marriage alliance and were probably both rivals of the Western Turks. Emperor Wen, therefore, probably wanted to secure support from the Eastern Turks as well as the Tuyuhun in case he needed assistance against the Western Turks. This is further corroborated by the fact that Emperor Wen agreed to a request for a marriage alliance made by the Eastern Turk qaghan. ${ }^{59}$ Princess Anyi 安義 was married off in 597, whereby the Eastern Turks became allies of Sui and thus provided them with military assistance as needed. Only two years later, Princess Anyi passed away, and the Sui court sent Princess Yicheng 義成 as a new wife. ${ }^{60}$ She would later play a crucial role in the conflict between the Eastern Turks and the Tang dynasty: As a former subject of the Sui, she would urge her husband to protect members of the Sui imperial family and wage war against the Tang. ${ }^{61}$

\subsection{Tang}

During the Tang dynasty, the Tuyuhun grew to fill a key position at the juncture between Tang China and the increasingly powerful Tibetan state. Tibet, rarely mentioned in Chinese sources in earlier centuries, rapidly grew stronger over the course of the seventhcentury. Due to its position sandwiched between the two large empires, the Tuyuhun state played an important role in the power struggle between Tang and Tibet. Both repeatedly tried to win the Tuyuhun over to their side, which split the Tuyuhun elite in pro-Tang and pro-Tibet factions. The rivalry between Tang and Tibet for influence over Tuyuhun reached its peak in the first half of the seventh century. Even though the Tuyuhun territory seemed secondary

56 Molè 1970, 43 .

57 Zizhitongjian 194.6112-6113.

58 Pan 1997a, 111; Sui shu 83.1844-1845.

59 Pan 1997a, 110; Sui shu 84.1872-1873.

60 Suishu 84.1872.

61 Pan 1997a, 112; Jiu Tangshu 194A.5159. 
compared to the huge Tang and Tibetan realms, it was of strategic importance. When the

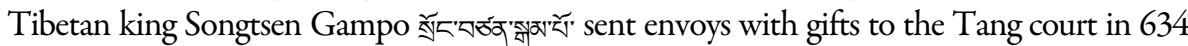
and asked for a bride, Emperor Taizong 太宗 (r. 626-649) refused, and Songtsen Gampo attacked the Tuyuhun and Tang borders. Afterwards, he sent envoys to the Tang court again, with the message that he would repeat the attacks if his son were not given a Chinese wife. Taizong agreed, and in 641, Princess Wencheng 文成 was sent to Tibet. ${ }^{62}$ The fact that the Tibetan king managed to force a marriage alliance on the Tang by attacking the Tuyuhun shows that the Tuyuhun must have been of importance to the Tang court at that time. Du Linyuan points out that the Tang wanted to use the Tuyuhun lands as a buffer in their conflict against Tibet and tried to avoid a direct confrontation with the Tibetan troops. ${ }^{63}$

Previously, in 635, after Tang forces had seized control over Tuyuhun territory, Murong Shun 順 (d. 635), the former hostage of Sui and later of Tang, was invested as Qaghan of the Tuyuhun by Emperor Taizong. Shun saw his chance to wrest power over the Tuyuhun from his half-brother with the support of the Tang Emperor, ${ }^{64}$ but he was assassinated by a rival in the same year. Taizong sent troops to ensure that a pro-Tang ruler would lead the Tuyuhun and installed Murong Shun's son, Murong Nuohebo, as the new ruler, but Nuohebo was young and not able to exert enough authority over his ministers. Taizong therefore sent his troops to support him. ${ }^{65}$ The examination of the epitaphs of the two Chinese princesses in the following section and in a wider context of the other family members of the ruling clan, will reveal that Nuohebo remained loyal to Tang until his death, and his descendants continued to do so for several decades.

Although Nuohebo had managed to keep his position as ruler thanks to the military support from Tang, disagreement among the Tuyuhun elite remained. In the following decades, the Tuyuhun maintained marriage alliances with the Chinese as well as the Tibetan court. The internal differences in allegiance manifested themselves in two groups, one faction forming around Nuohebo and his Chinese wife, Princess Honghua, ${ }^{66}$ and the other one probably around his uncle, the second son of the former ruler Fuyun, Zunwang 尊王, who had a Tibet-

62 Pan 1997a, 113-114; Jagchid and van Simons 1989, 155; Xin Tang shu 216A.6073-6074. It is often believed that Princess Wencheng was married to Songtsen Gampo. According to Beckwith 2009, 409410, she was in fact intended as a wife for his son, who died a few years later. It is unclear if Songtsen Gampo then also married the princess or if they just continued to live in the same household.

63 Du Linyuan 2002,78.

64 Skaff 2012,281; Xin Tang shu 221A.6226. No name is mentioned for this half-brother, but it might have been Zunwang 尊王, who was married to a Tibetan wife.

65 Jiu Tang shu 198.5300. A very similar passage can be found in Xin Tangshu 221A.6226.

66 See section 4.3.1 on Princess Honghua. by the author or by third parties is a copyright infringement and therefore prohibited. 


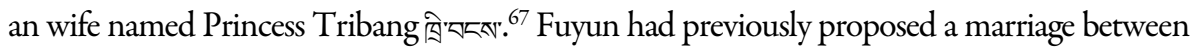
his son Zunwang and a Tang princess, so Emperor Taizong asked Zunwang to come to the court, but Zunwang feigned illness, and the marriage was not concluded. ${ }^{68}$ The Jiu Tang shu, furthermore, tells us about an incident in which one of Nuohebo's ministers secretly planned to attack Princess Honghua's escort, kidnap her, and then flee to Tibet. ${ }^{69}$ It is apparent that this minister opposed an alliance with Tang China and tried to sabotage it. Nuohebo learnt of this plot and fled to Shanshan 部善. ${ }^{70}$ Nuohebo and some of his loyal subjects defeated the minister and then informed the Tang emperor, who sent an official to pacify the situation. The Tuyuhun and Nuohebo's loyalty seem to have been of importance to Taizong: When Taizong died, images of Nuohebo and other leaders of foreign states were carved into stone and placed in his tomb. ${ }^{71}$

Tang's attitude towards the Tuyuhun and Tibet changed when Gaozong 高宗 (r. 649683) came to power. When skirmishes arose between the Tuyuhun and Tibet in 663, both asked for assistance, and he denied it to both parties. ${ }^{72}$ Around this time, the pro-Tibet faction overthrew Nuohebo's rule, and Nuohebo once again turned to Gaozong for assistance and protection. Nuohebo and his followers, amounting to several thousand tents, fled to Liangzhou 涼州 ${ }^{73}$ and remained loyal to the Tang court, while some Tuyuhun subjects stayed behind and pledged allegiance to Tibet. ${ }^{74}$ In the end, Nuohebo did not receive military support from Tang China to retake his territories. He did send his own troops in 670, but they suffered a crushing defeat at the hands of the Tibetan forces. In 672, Nuohebo and his followers were allowed to migrate to Tang territories. He passed away in $688 .^{75}$ The end

67 Lin 2011, 249, based on Yamaguchi 1983, 671-676. Interestingly, a fragment of a manuscript found in Dunhuang (British Library, IOL Tib J 1368r; see also Thomas 1927) might point to this marriage. The text tells us of a certain Queen Tribang, apparently a member of Songtsen Gampo's family, and her son

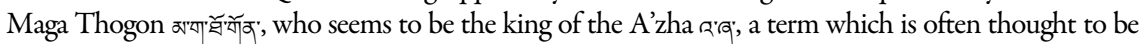
the Tibetan designation for the Tuyuhun (Pelliot 1920). A close reevaluation of this fragmentary text and further study of Tibetan sources are necessary to shed light on this matter, which is of great interest to the understanding of the marriage alliances between Tibet and the Tuyhun, as well as the political situation of the Tuyuhun at that time.

68 Pan 1997b, 235.

69 Jiu Tangshu 198.5300.

70 The present-day Ruoqiang 若美 (var. 婼美, Qakilik) County in Bayingolin Mongol Autonomous Prefecture 巴音郭楞蒙古自治州; see Tan 1982b, 9).

71 Jiu Tangshu 198.5300.

72 Jiu Tangshu 198.5300.

73 Present-day Wuwei, Gansu.

74 Skaff 2012,281.

75 Jiu Tangshu 198, 5300. 
of Nuohebo's rule is generally seen as the demise of the Tuyuhun state. Even though some of his descendants also received titles, the state was never revived. The family did, however, continue to intermarry with Chinese clans, as can be learned from their epitaphs. These were found in a group of tombs erected for the family members of Nuohebo and amount to eleven epitaphs in all. ${ }^{76}$ They clearly show regular participation in marital politics with Tang. In some cases, these were marriages on the highest level, i.e. when imperial princesses were given to a member of the Murong Tuyuhun family; in other cases, marriages were concluded with other influential Tang clans, such as the Wu 武 clan of Wu Zetian 武則天 (r. 690-705). ${ }^{77}$ The following pages will focus on the translation and analysis of two of these epitaphs, namely the ones dedicated to the Chinese princesses Honghua and Jincheng.

\subsubsection{Princess Honghua}

Princess Honghua was the first of three Tang princesses to be married to a Tuyuhun leader. She was born in 622, perhaps as a daughter of Li Daoming 李道明, the king of Huaiyang 淮陽. ${ }^{78}$ She was given in marriage to Murong Nuohebo in 640, at the age of 18. After Wu Zetian became empress in 690, Princess Honghua was invested with the highest princess title, "Grand Elder Princess Xiping (Xiping Dazhang Gongzhu 西平大長公主) of the Great Zhou Dynasty" ${ }^{79}$ but for the sake of clarity, we will still refer to her as Princess Honghua throughout the text.

The marriage alliance between the Tang court and Murong Nuohebo is mentioned in the Jiu Tang shu and the Xin Tang shu. The entry in the Xin Tang shu ${ }^{80}$ tells us that Nuohebo went to the court to thank Emperor Taizong for military support he had previously received and to ask for a marriage alliance. He also brought ten thousand horses, oxen, and sheep as a gift. When he came to the court in the following year, a daughter of the imperial

76 For studies on these tombs, see Xia 2002; Du Linyuan 2002; Yu 2013.

77 See Du Linyuan 2002; Yu 2013.

78 Li Zhanzhong 2003, 40. It is unclear where the author found this information. The Jiu Tang shu mentions a "Daoming, King of Huaiyang," who brings the imperial insignia to the Tuyuhun court after Nuohebo has attained leadership of it. He is also the person who escorted Princess Honghua to the Tuyuhun and later planned to kidnap her, as well as being the person who revealed that she was not a real princess (Jiu Tang shu 198.5300, 60.2354; Xin Tang shu 221A.622). But it is not recorded that he was her father.

79 As mentioned above, this title was usually given to paternal aunts of the emperor. Based on Princess Honghua's case, we can assume that it was also given to women who were of high status or whose marriage was of great importance to the imperial court.

80 Xin Tangshu 221A.6226; see also the slightly shorter entry in Jiu Tangshu 198.5300. 
family received the title of "Princess Honghua" and was given to him as a wife. ${ }^{81}$ Nuohebo was moreover presented with various valuable gifts.

An epitaph for Princess Honghua was unearthed during the excavation of her tomb in Wuwei, Gansu. No official excavation report on her tomb has yet been published, and the epitaph has not yet been translated into another language. Even though the inscription gives little information on the marriage itself, we can still gain some knowledge about her life and her status, keeping in mind that many epitaphs were written to record and often embellish a person's virtues and deeds for the following generations and were therefore not always exactly truthful. ${ }^{82}$ Along with the style and length of the text, its contents can still prove useful when assessing the deceased person's status. This epitaph is therefore a valuable addition to the material we have from transmitted historical texts. No thorough study of her epitaph or her tomb exists to date. ${ }^{83}$ Thus, research on this matter is of great significance for studies on the Tuyuhun. According to Li, the tomb was originally filled with valuable burial objects such as bronze artifacts, painted tomb figurines, jade objects, pearls, and textiles. ${ }^{84}$ The epitaph consists of text on the lid and the bottom of the tombstone. ${ }^{85}$ The lid bears the title of the inscription, which is arranged in three columns of three characters and written in seal script. The title reads: "Da Zhou gu Xiping gongzhu muzhi" 大 周故西平公主墓誌 (Epitaph of the Deceased Princess Xiping of the Great Zhou Dynasty).

81 According to Li Zhanzhong 2003, 41, Nuohebo went to Chang'an 長安 in the winter of 639 to welcome Princess Honghua as his bride. The author does not indicate where he found this information. According to the passage cited above from the Jiu Tang shu 198.5300, the marriage took place in 640.

82 See Ditter 2014, 37-42.

83 Even though some Chinese articles have been written on Princess Honghua, they often seem to be influenced somewhat by ideology, implying that the princess brought the advanced Chinese culture to the backwards Tuyuhun, e.g. Li Zhanzhong 2003; Li Li 2010. This author knows of no prior study in a Western language on Honghua's tomb or her epitaph.

84 Li Zhanzhong 2003, 41. Unfortunately, the tomb was robbed several times, and its structure was heavily damaged. The walls were covered with colorful paintings, but today only fragments of these remain. The only objects left are Princess Honghua's remains, over 50 painted wooden objects, and fragments of textiles, lacquerware, and wooden objects. Among the painted wooden objects are several painted tomb figurines of men and women as well as parts of horses and camels.

85 Both parts are made of sandstone and are rectangular, measuring $68 \times 68 \mathrm{~cm}$. Rubbings of the epitaph are published in Li Longwen 2009, 12-13. See also ills. 2,3. 


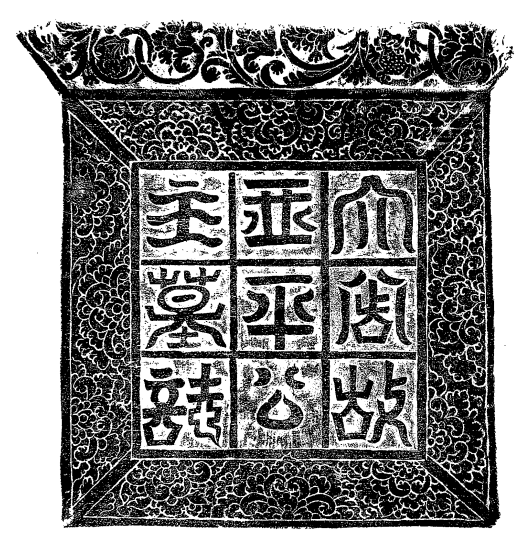

Ill. 2: Lid of Elder Princess Honghua's epitaph. Sandstone, $68 \times 68 \mathrm{~cm}$. Unearthed in Wuwei, Gansu (Li Longwen 2009, 13)

The edges of the lid are decorated with a border containing floral elements. The body of the epitaph consists of an inscription containing 25 columns with 24 characters per column, which makes a total of 600 characters. It dates to 699 , during the reign of Empress Wu. We can discern several variations of Chinese characters, some of which were introduced by Empress $\mathrm{Wu}$ with the goal of emulating archaic forms of characters. ${ }^{86}$ Other character variants found in Honghua's epitaph may be classified as demotic (suzi 俗字).

86 See also Galambos 2014; Drège 1984. In this epitaph, we find the following characters introduced by

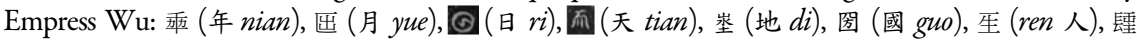
(sheng 聖), 薁(載 zai). 


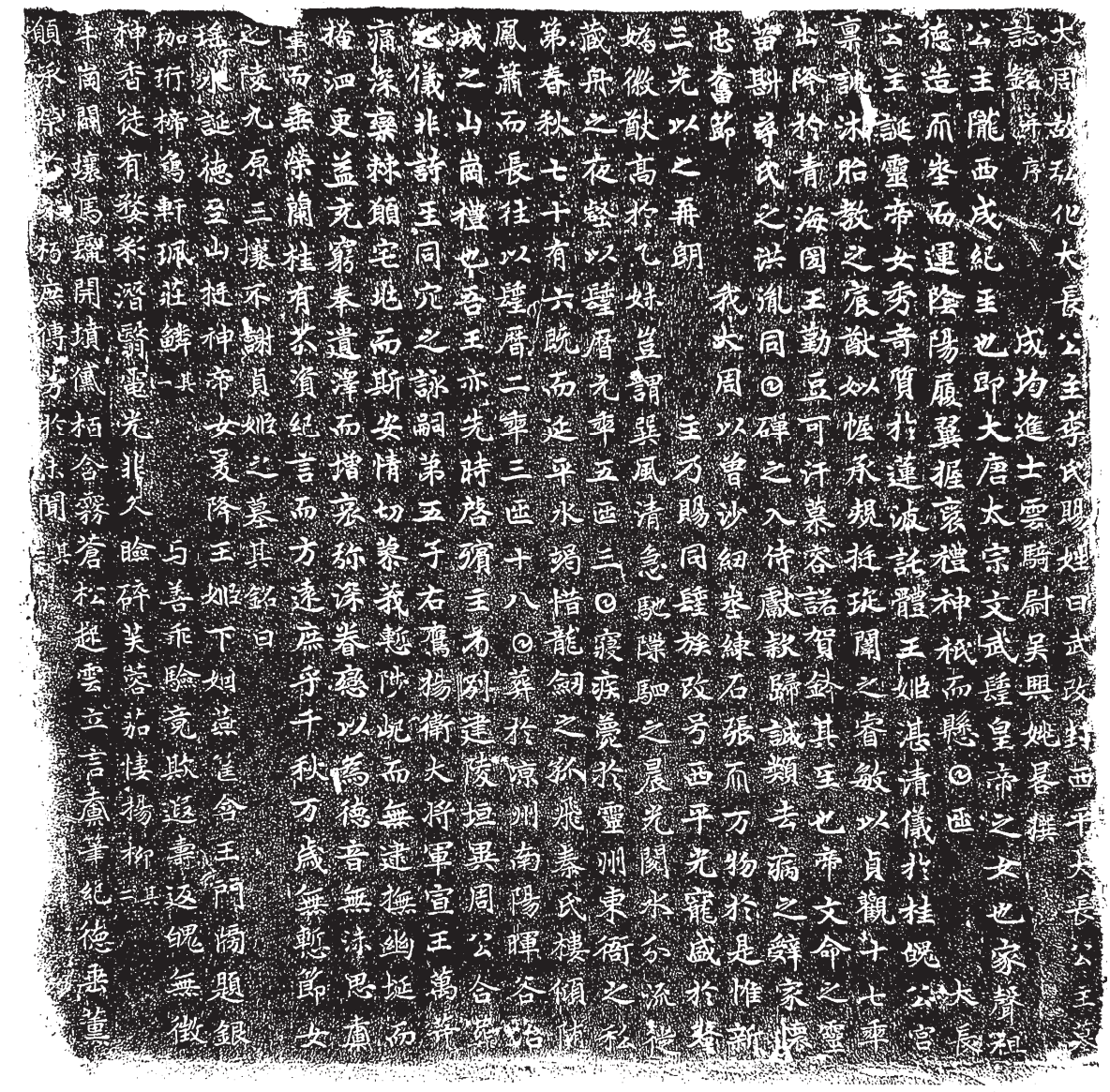

Ill. 3: Elder Princess Honghua's epitaph. Sandstone, 68 x 68cm. Unearthed in Wuwei, Gansu (ibid, 12)

${ }^{[1>}$ 大周故弘化大長公主李氏賜姓日武改封西平大長公主墓 ${ }^{[2>}{ }^{2}$ 銘并序 $^{87}$ Epitaph of the deceased Grand Elder Princess Honghua of the clan Li, bestowed with the surname "Wu" and newly invested with the title of Grand Elder Princess Xiping of the Great Zhou Dynasty (Preface)

$\square \square \square$ 成均進士雲騎尉吴興姚 (姚) 㫡撰

Written by Yao Gui ${ }^{88}$ of Wuxing, ${ }^{89}$ Presented Scholar of the National Academy ${ }^{90}$ and Cavalry Commandant of the Clouds

87 The columns of the inscription have been numbered to allow for easier comparison between the rubbing and the transcription. Intentional spacing in the inscription is also represented in the transcription.

(C) Harrassowitz Verlag, Wiesbaden 2019

This PDF file is intended for personal use only. Any direct or indirect electronic publication by the author or by third parties is a copyright infringement and therefore prohibited. 
[3>公主隴西成紀有 (人) 也. 即大唐太宗文武蕻 (聖) 皇帝之女也. 家聲祖 ${ }^{[4>}$ 德, 造天程 (地) 而運陰陽. 覆翼握售, 禮神祇而懸目(日)出(月).

The princess was a person from Chengii in [the district of] Longxi. ${ }^{91}$ She was thus a daughter of the Sacred Emperor Wenwu, Taizong of the Great Tang [dynasty]. ${ }^{92}$ Her ancestry is of glorious reputation, and her forefathers were rich in merits and virtues. They have created Heaven and Earth and moved the Yin- and Yang-forces. She was covered by wings ${ }^{93}$ and held on to dignity. [Her ancestors] followed the rites for the gods and hung the sun and the moon [in the sky].

$\square \square \square$ 大長 $^{[5>}$ 公主誕靈帝女, 秀奇質於蓮波. 託體王姬, 湛清儀於桂魄. 公宮 [6>禀訓, 沐胎教之宸猷. 姒幄承規, 挺珤闈之点敏. 以貞觀十七杵 $(\text { 年 })^{[7>}$ 出降 於青海图 (國) 王勤互可汗慕容諾賀鉢.

The grand elder princess had a numinous birth as a daughter of the emperor. Her graceful singularity was assessed at the lotus pond..$^{93}$ She offered herself to be of service to the imperial court as an imperial daughter. Her demeanor was as clear and pure as the moon..$^{95}$ In the palace, she received instructions on the rules of the imperial apartments with regards to washing her hair and having a positive influence

88 Yao Gui was a member of the well-known Yao 姚 family. He received his titles in the same year he wrote the epitaph for Princess Honghua; see Han 1995, 13.

89 Present-day Huzhou 湖州 in Zhejiang Province; see Han 1995, 13.

90 In Xia 2002, 246, for some reason 崶 (地) 成均進士 is transcribed, even though the rubbing of the original clearly shows that the character $d i$ 花 (地) does not appear in this passage.

91 The district of Tianshui 天水 in present-day Qin'an 秦安, Gansu Province; see Tan 1982b, 62. As Longxi was traditionally recorded as the hometown of the imperial family, it is doubtful that she really was from Chengii in Longxi District. It is therefore possible that this information was "forged", to make her imperial lineage more believable.

92 We know that she was not one of his daughters. The author of the epitaph might have consciously constructed this connection to create the impression that she was a princess not only by title but also by blood, a fact that was crucial to marital politics.

93 In Xia 2002, 246, this passage is transcribed as 履翼握衰, deciphering the first character as lü 履. Even though character variants similar in form to that which appears in the inscription can be found as alternative forms of 履, this reading does not make much sense in this context. Another possibility is to read it as $f u$ 覆. This passage might then be an allusion to the poem no. 245 (“Sheng min”生民) from the Shijing 詩經 (Classic of Odes), describing Lord Millet's (Houji 后稷) miraculous birth and youth; see Shijing, 331-338; Simon 2015, 602; Karlgren 1950, 199-202.

94 The expression "lotus pond" is probably connected to lianhuafu 蓮花府, which at that time was a designation for the military administration; see Li Lianxiang 2009, 346. This office usually had a lotus pond at its entrance.

95 Guipo 桂螝, “the soul of the osmanthus", is a designation for the moon; see Wang and Tian 1990, 104. This expression probably derived from yuegui 月桂, which was a popular reference to the moon during Tang times. It might have its roots in the legend of the "Jade hare" ( yutu 玉兔), who is said to live in the moon and to create the drugs of immortality under an osmanthus tree (Williams 1988, 278). by the author or by third parties is a copyright infringement and therefore prohibited. 
on the unborn baby during pregnancy ${ }^{96}$ in the tent of $\mathrm{Si}^{97}$ she received the rules. She upheld the wise teachings of the female palace quarters. In the seventeenth year of the Zhenguan era, ${ }^{98}$ she was given as a wife to Wise Qaghan ${ }^{99}$ Murong Nuohebo, King of Qinghai.

其生 (人) 也, 帝文命之靈 ${ }^{[8>}$ 苗, 勘寻氏之洪胤, 同四 (日) 磾之入侍, 獻款歸誠. 類去病之辭家, 懷 ${ }^{[9>}$ 忠奮節.

As a person, she was like a spiritual seed of Emperor Wenming ${ }^{100}$ and like a great descendant of the Zhenxun ${ }^{101}$ clan. Just like [Jin] Midi, ${ }^{102}$ who entered service [at

96 Reference to this practice of taijiao 胎教 can be found in texts dated to as early as the Western Han. It is recorded in the Lienü zhuan 列女傳 (Biographies of Exemplary Women) 1.14 that Tai Ren 太任, the mother of King Wen of Zhou, was careful not to expose her unborn baby to bad influences. Therefore, her son was already an enlightened sage when he was born.

97 This probably refers to Wen $\mathrm{Si}$ 文姒, sometimes also called Tai $\mathrm{Si}$ 太姒. She was the wife of King Wen of Zhou and King Wu's mother; see Behnke Kinney 2014, 6-8.

98 The year 643 .

99 The title Qindou Kehan 勤豆可汗 seems to have first been used for Nuohebo. Qin 勤 might possibly be a borrowing, as it has been used as an element in titles among other groups, e.g. in titles for Xiongnu royalty. It is found in teqin 特勤 (retraced by Pulleyblank to Turkish "tegrin" and reconstructed as EMC *dək-giən), which was the Tang transcription for an earlier form of the title tuqi 屠者 (EMC *dou-gii); see Pulleyblank 1962, 257-258. Pulleyblank suggests translating this as "wise", parallel to Turkish bilgä, but he points out that the original meaning, which was lost over the centuries, must have been something like "prince". As for dou 立, I follow the suggestion in Pelliot 1920, 330, that 豆 might be the suffix -tu, which is used after attributes in Mongolian. In Pulleyblank 1991, 81, 豆 is reconstructed as $\mathrm{EMC}^{*} \mathrm{~d} w^{\mathrm{h}}$. It could have therefore been the Chinese character used to write -tu. Moreover, contrary to Classical Mongolian, Old Mongolian distinguished grammatical gender; see Hambis 1946, 1. Masculine adjectives were marked with the suffix - $t u$, while feminine adjectives added -tai. As discussed in section 2, the language of the Murong Xianbei was probably part of a sister branch of the Mongolic languages; it is therefore quite possible that a suffix - $t u$ with a similar meaning existed in the Murong Xianbei language and that Qindou Kehan can be translated as "Wise Qaghan".

100 Wenming is another name for the legendary Yu 禹, who was traditionally seen as an ideal ruler; see Shiji 2.49 .

101 The clan name of Yu's descendants; see Shiji 2.89.

102 Jin Midi 金日磾 was an official of Xiongnu origin who served under Emperor Wu 武 of Han (156 BC-87 BC). When Emperor Wu realized that his reign was ending, he decided to make his youngest son, Prince Fuling 弗陵, the heir apparent, but the prince was only six years old at the time. Therefore, the emperor entrusted his son to Jin Midi, Shangguan Jie 上官桀, Sang Hongyang 桑弘羊, and Huo Guang 霍光. They were to be coregents until the prince came of age. The epitaph alludes here to the fact that Jin Midi did not enter service to the Han out of his own free will but because his family members were taken as servants when their area was surrendered to the Han forces. Nevertheless, he still served loyally and became an important official at the Han court. A biography of Jin Midi can be found in Han shu 68.2959-2969. In a similar manner, Princess Honghua probably did not choose to be marby the author or by third parties is a copyright infringement and therefore prohibited. 
the imperial court], she surrendered and pledged her allegiance. Just like Lei Qubing, ${ }^{103}$ she had to bid farewell to her family, but her heart was filled with loyalty, and her brave actions showed integrity.

$\square \square \square$ 我大周以曾沙紐峚 (地) 練石張天, 万物於是惟新, ${ }^{[10>}$ 三光以之再朗. $\square \square \square$ 主乃賜同蕻 (聖) 族, 改号西平. 光竉盛於鳌 ${ }^{[11>}$ 媯, 徽猷高於乙妹. 峘謂 巽風清急, 馳隟駟之晨光. 閱水分流, 徙 ${ }^{[12>}$ 藏舟之夜壑.

Our Great Zhou dynasty connected the lands through Buddhist monks, and covered the sky with temples. ${ }^{104}$ The 10,000 things are [now] renewed and the three lights ${ }^{105}$ are shining bright again. The princess received the same offerings as the clan of the sages [from then on]. ${ }^{106}$ Her title was changed to [Grand Elder Princess] Xiping. Her favor ${ }^{107}$ reached its height when she was married. ${ }^{108}$ In her selfcultivation, she [even] surpassed [Emperor] Yi's younger sister. ${ }^{109}$ How can one call the southeastern wind cold and irritable ${ }^{110}$ [when human life is like] a fast

ried to a Tuyuhun ruler, and the inscription implies that she was initially unhappy about this arrangement, but she still saw it as her duty to the emperor and therefore pledged to serve loyally.

103 Lei Qubing 類去病 refers to Huo Qubing 霍去病 (140-117 BC). He was a high-ranking military official under Emperor Wu and the half-brother of the aforementioned Huo Guang. Emperor Wu ordered the 18-year-old Huo Qubing to lead a military expedition against the Xiongnu in $121 \mathrm{BC}$, the very expedition which would later lead to Jin Midi being taken as a servant to the Han capital. He devoted his life to defeating the Xiongnu and was therefore far away from home in foreign lands; see also Shiji 111.2928-2931. Huo Qubing's story was later often used in poetry as an allusion to battle in the borderlands; see Li Lianxiang 2009, 255.

104 I read the character zeng/ceng 曾 in the inscription as seng 僧. Lianshi 練石 is probably an orthographic variant of lianruo 練若. This expression is an alternative form of the Buddhist term alanre 阿蘭若, which is a transcription of the Sanskrit term aranya, meaning "secluded place, wilderness"; see Ding 1929, 2512; Chen and Li 2005, 2. This term originally referred to the secluded hut of an itinerant monk. Later, it also came to be used as a name for Buddhist temples. The use of Buddhist symbolism was very present during Empress Wu's reign; see Chen Jinhua 2002, 62.

105 Sun, moon, and stars; see Wang and Tian 1990, 255; Li Lianxiang 2009, 509-510.

106 A reference to the fact that she was invested with the surname $\mathrm{Wu}$ 武, the imperial surname of the Zhou dynasty.

107 The term used here is guang chong 光寵, often used to express that a woman became pregnant.

108 The expression used in the inscription is li Gui 整媯, which refers to an anecdote in Shangshu尚書 2.46: The legendary emperor Yao 堯 sent his two daughters to marry Shun 舜, who lived on the banks of the Gui River. In this way, Yao hoped to test Shun's behavior towards the two women. In later times, this story was often used to refer to noble daughters, who were sent away in marriage.

109 This refers to the younger sister of Emperor Yi 乙 of the Shang dynasty. In Hanji 漢記 17.177, it is recorded that he gave her away in marriage.

110 Xun feng 巽風; xun 巽 is the fifth trigram in the divinatory system of the Eight Trigrams in the Yijing 易 經 (Classic of Changes), which is associated with the wind, the direction southeast, a gentle personality, and the eldest daughter in Han correlative cosmology. The southeastern wind might represent Princess by the author or by third parties is a copyright infringement and therefore prohibited. 
horse galloping towards a crevice in the dawn? ${ }^{111}$ Collecting the water and dividing its flows [is just like] the nocturnal ravine of the hidden boat. ${ }^{112}$

以蕻 (聖) 曆元开 (年) 五出 (月) 三四 (日) 寢疾, 夢於靈州東衙之私 ${ }^{[13>}$ 第, 春秋 七十有六. 既而延平水竭, 惜龍劍之孤飛. 秦氏樓傾, 随 ${ }^{[14>}$ 鳳簫而長往. 以蕻 (聖) 曆二秓 (年) 三拙 (月) 十八目 (日) 葬於涼州南陽暉谷冶 ${ }^{[15>}$ 城之山崗, 禮 也.

On the third day of the fifth month of the first year of the Shengli era, ${ }^{113}$ the princess passed away in her private rooms in the eastern part of the palace in Lingzhou. ${ }^{114}$ She had been in bed due to an illness for some time and died at the age of 76. Soon after, the waters [at the ford of] Yanping dried up, and the dragon sword regretfully took up its lonesome flight. ${ }^{15}$ [Just like] the Qin clan, who died on the [phoenix] terrace, she followed the phoenix flute ${ }^{116}$ and passed away. On

Honghua, implying that she in fact had a gentle personality and was, contrary to what was apparently said about her, not of a cold and irritable nature.

111 According to Wang and Tian 1990, 434, 577, the term xisi 桚駆 is equivalent to the expression guo xiju 過隟駒, which goes back to a passage from the Zhuangzi 莊子; see Chen Guying 1983, 570. This expression later came to be used as an allusion to the briefness of human life. On guo xi 過策, see also $\mathrm{Li}$ Lianxiang 2009, 206.

112 The term cang zhou 藏舟 can also be found as cang he 藏壑; see Wang and Tian 1990, 384-385. This expression also goes back to a story in the Zhuangzi (Chen Guying 1983, 178) and alludes to the fact that the nature of heaven and earth cannot be prevented or changed. It can also refer to the short duration and insignificance of human life in comparison to nature.

113 18th of the 4th month in 698.

114 South of present-day Yinchuan 銀川, the capital of Ningxia 寧夏 Autonomous Region; see Tan 1982b, 32).

115 Yanping 延平 and long jian 龍劍 both refer to the story of two supernatural swords that dove into the water at the ford of Yanping and turned into dragons. The expression long jian is comparable to Fengchengjian 豊城劍 (the swords of Fengcheng), which was sometimes used to describe family members or close friends who were separated and were about to reunite with each other; see Li Lianxiang 2009, 365; Wang and Tian 1990, 418, 482. The dragon sword mentioned here probably symbolizes Princess Honghua reuniting with the other sword, her husband Nuohebo, who already had passed away at that time.

116 The inscription refers to the story of Nongyu 弄玉, the daughter of Qin Mugong 秦穆公 (r. 659-621 BC); see Liexian zhuan 列仙傳 (Biographies of Exemplary Immortals), 80. One day, the flute player Xiao Shi 簫史 (Scribe Flute) came to their palace. He liked Nongyu, so her father gave her to Xiao Shi as a wife. He taught her how to play the flute, and after a few years, she was able to imitate the sound of the phoenix. This sound attracted a phoenix, which perched on the roof of the palace. The duke built a phoenix terrace and the couple stayed there for several years. One morning, they followed the phoenix and flew away. The figure of Nongyu later came to represent sages, but also princesses and beautiful women; see Wang and Tian 1990, 499-500. 
the 18th day of the third month of the second year of the Shengli era, ${ }^{117}$ she was buried in the hills of Huiguye near Nanyang in Liangzhou. Everything was carried out in accordance with the rites.

吾王亦先時啟殯, 主乃別建陵垣, 異周公合葬 ${ }^{[16>}$ 之儀, 非詩生 (人) 同穴之詠 (咏). 嗣第五子右鷹揚衛大將軍宣王萬菽 ${ }^{[17>}$ 痛深變棘, 願宅圷 (兆) 而斯安.

Because my king [Nuohebo] had also previously received a funerary procession, ${ }^{118}$ a seperate tomb mound and wall was built for the princess [Honghua]. This differs from the rite of joint burial of the Duke of Zhou and does not conform to the singing of poets in their common burial chamber. [Nuohebo's] successor and their fifth son, [Murong] Wanshu, ${ }^{119}$ Great General of the Right Guard of the Soaring Hawk and King of Xuan, was filled with the deep grief of a loyal son who has lost a parent. He longed for the graveyard and wanted to rest in its peacefulness.

情切苓莪, 慙陟屺而無逮. 撫幽埏而 ${ }^{[18>}$ 掩泗, 更益充窮. 奉遺澤而增哀, 弥深 眷戀. 以為德音無沫, 思載 ${ }^{[19>}$ 筆而垂榮. 蘭桂有芬, 資紀言而方䢡. 庶乎千秋 万歲, 無慙節女 ${ }^{[20>} 之$ 陵. 九原三壤, 不謝貞姬之墓.

His feelings were sincere, [just as in the poem] "Lu e". ${ }^{120}$ He felt shameful, [just as in the poem] "Zhi qi" ${ }^{121}$ that he did not make it back [in time]. As he was leaning on [the wall of the] tomb passage, his face covered in tears, his feeling of loss was growing ever stronger. He made an offering to her remains, which increased his grief [even more]. [He was] filled with deep reluctance to part [with his mother]. He [wanted to] express her virtue for all eternity, so he took his brush and wrote down [a few lines for her], in order to revive her radiance. The lotus and osmanthus are fragrant. Providing a record of these words, [I] will leave. For a thousand autumns and ten thousand years, the tomb of this pure lady will be nothing to feel

117 The 23rd of the 2nd month of 699.

118 Nuohebo had passed away ten years earlier in 688; see Jiu Tang shu 198.5300.

119 In Xia 2002, 246, these two characters are read as Wan deng 萬等, but the second character in the rubbing more closely resembles a variation of $s h u$ 菽 than 等. A reading as 菽 furthermore implies that the name of Nuohebo and Honghua's fifth son was in fact not Wan, but possibly Wanshu.

120 “Lu e" 蓼莪 refers to poem 202 of the Shijing, in which the author mourns the passing of his parents, who died due to his inability to support them in their time of need; see Shijing, 293-297; Simon 2015, 476-479; Karlgren 1950, 152-153. This reference suggests that Wanshu himself was perhaps away, when his mother was on her deathbed.

121 “Zhi hu” 陟岵 is another poem (no. 110) from the Shijing. See Shijing, 138-140; Simon 2015, 238; Karlgren 1950, 70. It is interesting to note that the inscription uses the character 屺 instead of 岾. This might be a mistake by the author. However, in the poem, 屺 appears in the line which refers to the mother. Therefore, it could also be a conscious substitution by the author. This poem was later used as an allegory for the filial son who misses his mother. by the author or by third parties is a copyright infringement and therefore prohibited. 
shameful about. May the nine sources ${ }^{122}$ and the three soils ${ }^{123}$ not let the tomb of this chaste woman disappear.

The epitaph ends with three pieces of parallel prose, presumably written by Princess Honghua's son Murong Wanshu, which are presented below:

[21>瑤水誕德, 巫山挺神, 帝女爰降, 王姬下姻,

燕筐含玉, 門牓題銀, ${ }^{[22>}$ 珈珩楴象, 軒珮莊鱗其一

与善乘驗, 竟欺遐壽, 返魄無征, ${ }^{[23>}$ 神香徒有,

惣彩潛贀, 電光非久, 瞼碎芙蓉, 茄悽揚柳其二

[24>牛崗闢壤, 馬镾開墳, 黛柏含霧, 荅松起云

立言載筆, 紀德垂薰, ${ }^{[25>}$ 願承榮於不朽, 庶傳芳於未聞其三

It would go beyond the scope of this article to translate and discuss them here in detail, but it can be said that they, just like the rest of the text, abound with imagery from Chinese poetry, allusions to anecdotes from Chinese history, and references to the Chinese classics. ${ }^{124}$

The language of the inscription is very refined and poetic. Several set expressions appear that are typically used in epitaphs, which demonstrates that this inscription was in accordance with the current Chinese style and norms of epitaphs. These observations point to the high status Princess Honghua enjoyed during her lifetime. Moreover, her epitaph is relatively long when compared to epitaphs for other princesses, which would have meant that the cost of commissioning the text was higher. The name of its author is given as Yao Gui, and we know that he came from a well-known family. From the inscription, we learn that he was awarded the title of "Presented Scholar", which reflects his high literary ability. Princess Honghua's family-members would have been most certainly willing to spend a considerable sum of money on commissioning the epitaph from this well-read author. Unfortunately, many of the funerary objects have been destroyed since the discovery of the tomb, ${ }^{125}$ but

122 Jiu yuan 九原 (nine sources), usually refers to the ground below and in a wider sense to the place where the departed are buried; see Wang and Tian 1990, 150. Apart from a graveyard, it can also signify the “yellow spring” huang quan 黄泉; see Li Lianxiang 2009, 309. Possibly a variation of the term jiu quan 九泉.

123 San rang 三壤 (three soils) is probably parallel to the juu yuan mentioned above. According to Wang and Tian 1990, 255, there is an expression san quan 三泉 (three springs), which is equivalent to jiu quan.

124 In these pieces of parallel prose, the son Murong Wanshu expresses his grief over the loss of his beloved mother. Each piece consists of eight lines of four characters, except for the last two lines of the third piece, which are six characters long. Every other line is rhymed, resulting in a rhyme pattern of " $\mathrm{x}-\mathrm{A}-\mathrm{x}$-A$\mathrm{x}$-A-x-A", i.e. a typical gushi 古詩 pattern.

125 LiZhanzhong 2003, 42. 
from her epitaph we can deduce that her tomb rather strongly reflected current Chinese funerary practices. Two observations support this postulation: the simple fact that an epitaph was written at all, a tradition which at that time had already been practiced for centuries among the Chinese elite but not necessarily among the Tuyuhun; and the text itself, which is filled with references to the Chinese classics, history, and poetry. ${ }^{126} \mathrm{~A}$ comparison with the other epitaphs found in this group of tombs reveals that Princess Honghua's epitaph was not an oddity among otherwise "barbarian" tombs. All of the eleven epitaphs demonstrate a certain awareness of the relevance of epitaphs to Chinese funerary practices and a familiarity with Chinese culture.

It is very plausible that the use of a distinct Chinese style in the epitaphs was a conscious choice made by the pro-Tang faction of the Tuyuhun as a statement against Tibet. By the time these tombs were created, the Tuyuhun state had already disintegrated and the lands were under Tibetan rule. It is certainly no coincidence that the tombs were discovered in Wuwei, the former Liangzhou, where Nuohebo and other Tang loyalists sought refuge after they had lost control over their territories. The strong Chinese influence that may be perceived in the epitaphs might be a last statement by the remaining pro-Tang members of the former Tuyuhun ruling clan against the Tibetan conquest of their former homeland. When he came to power in 635 , Nuohebo was only able to maintain his position as ruler with help from Tang troops. This fact probably explains his life-long loyalty to the Tang court. Moreover, his father Shun spent several years in Chang'an, first as a hostage of the Sui and then the Tang. ${ }^{127}$ It is possible that Nuohebo was born there and spent his early childhood in Chang'an. No information on Nuohebo's mother has been transmitted, but it is possible that he was partly of Chinese descent. He might even have had some Chinese education, which would explain a certain appreciation of Chinese classics and culture, which he might have passed on together with his Chinese wife, Princess Honghua.

126 According to Li Zhanzhong 2003, 43, Princess Honghua's tomb reflects Tuyuhun funerary practices as well as their material culture. I cannot agree with this statement for two reasons: Firstly, we simply do not know enough about Tuyuhun funerary practices and their material culture to be able to discern typical Tuyuhun elements in this or any given tomb. Secondly, there are elements in this tomb, such as the epitaph, that clearly belong to the Chinese funerary culture. Moreover, we should consider the fact that Princess Honghua herself was of Chinese origin and that she might have wished for a funeral in accordance with Chinese rites. Thus, this tomb does not reflect the Tuyuhun culture as a whole. As we have stated earlier, the term Tuyuhun probably did not actually designate an ethnic unity but more of a conglomeration of several ethnic groups that lived in this territory, all of which may have had their own rites and conventions when it came to funerals.

127 Xin Tangshu 221A.6226. by the author or by third parties is a copyright infringement and therefore prohibited. 
Much work remains to be done on materials excavated in Tuyuhun territory in order to paint a clearer picture of their (material) culture, funerary practices, and the way they positioned themselves in relation to the Chinese. Princess Honghua's epitaph provides the first strong indication that some members of the Tuyuhun ruling elite of Tang times were quite conversant with Chinese classics and familiar with popular poetic imagery of the time. This observation contradicts the image of the uncultured and rough barbarian and leads us to question the relevance of ethnic categorization in the discussion of marriage alliances during Tang. It seems that strict labels of ethnicity do not accurately reflect the reality of the period and that pragmatic and political considerations were more important for marital politics.

\subsubsection{District Princess Jincheng}

The epitaph of District Princess ( xianzhu 縣主) Jincheng 金城 was also found in the same group of tombs located in Wuwei. Even though the style of writing is much more neutral than that of the epitaph for Princess Honghua, the text still corroborates the strong adherence to Chinese norms. Princess Jincheng was the wife of the eldest son of Murong Nuohebo and Princess Honghua. This marriage alliance seems to have been decided upon in 652; the exact date of marriage is, however, not certain. According to the Xin Tang shu ${ }^{128}$ Princess Honghua sent an envoy to Chang'an when Emperor Gaozong acceded to the throne in 650 and requested to be allowed entry to the court. When she and Nuohebo arrived at the imperial court several months later, the emperor gave a daughter of a removed branch of the imperial family, District Princess Jincheng, to their oldest son Sudu Momo 蘇度摸末 as a wife. ${ }^{129}$ Interestingly, the request for marriage was made by Princess Honghua, who herself was married to the Tuyuhun leader Nuohebo a few years earlier. Apparently, she supported the use of marriage with the goal of forging closer relations between Tuyuhun and Tang, and therefore wished for Chinese princesses for her own sons. Thus, it becomes clear that the faction of the Tuyuhun elite loyal to Tang actively sought to ally themselves with the Tang through marriages with a political motive in mind.

Like the other epitaphs of the Tuyuhun royal family found in Wuwei, this one consists of a lower stone, which bears the inscription, as well as a lid. Both parts are made of sandstone

128 Xin Tangshu221A.6227.

129 Sudu Momo seems to be his Tuyuhun name, which can be reconstructed as EMC *So-do ${ }^{\mathrm{h}}$ mo-mat. Another possible reading is Suduo Momo, which gives a reconstruction as *So-dakmo-mat. These reconstructions are based on Pulleyblank 1991. On the identity of Sudu Momo, please see also the discussion below. 
and measure $37 \mathrm{~cm} \times 35 \mathrm{~cm} .{ }^{130}$ The lid bears the title of the epitaph, written in seal script. On the edges of the stone, the characters of the twelve terrestrial branches appear, except for $w u$ 午, which is replaced by $m a$ 馬. ${ }^{131} \mathrm{~A}$ floral pattern is visible in each corner of the lid. The inscription itself is 16 columns long, with 16 characters per column. This gives a total of 256 characters, all written in regular script. According to Xia, a grid was painted onto the stone before the text was inscribed, ${ }^{132}$ probably to make sure the characters were spaced evenly and written in approximately the same size. The inscription most likely dates to 719 , the year when the burial of District Princess Jincheng took place. To my knowledge, no official excavation report exists, but Xia Nai recorded his experiences during the excavation in his diary. ${ }^{133}$ Later, he also wrote a detailed article on the epitaphs of District Princess Jincheng and her husband Murong Zhong 慕容忠. ${ }^{134}$ The inscription for District Princess Jincheng reads as follows:

大唐金城縣主墓誌銘

Epitaph of District Princess Jincheng of the Great Tang

縣主諱季英, 隴西人也. 七代祖瀛州刺史宣簡公, 六代祖唐宣皇帝, 高祖唐先 皇帝, 曾祖定州刺史乞豆, 祖開化郡王文, 父交州大都督、會稽郡王道恩, 縣 主即王之第三女也.

The name of the district princess was Jiying. She was from Longxi, ${ }^{135}$ a descendant in the seventh generation of Xuan Jiangong, Prefect of Yingzhou. ${ }^{136}$ She was a descendant in the sixth generation of Emperor Xuan of the Tang. Her great-greatgrandfather was Emperor Xian of the Tang and her great-grandfather the prefect of Dingzhou, Qi Dou. Her grandfather was King Wen from Kaihua Command-

130 As no published images of the epitaph are available, the following descriptions rely on Xia Nai's observations in Xia 2002, 210-252.

131 The horse is the animal associated with this terrestrial branch. Princess Jincheng passed away in the year of the horse (718), which might explain why 馬 was used instead of 午.

132 Xia 2002,210.

133 Xia 2011.

134 Xia 2002.

135 The area around present-day Longxi in Gansu Province; see Tan 1982a, 55. According to Xia 2002, 211, this piece of information might be incorrect, as it is recorded that during the Northern and Southern Dynasties, the "ways of the barbarians" were followed in Longxi. But we should take into consideration that Longxi was normally recorded as the native place of the members of the imperial Li clan. It is more plausible that this piece of information was added to emphasize District Princess Jincheng's connection to the imperial ruling house. Moreover, we know that the Li clan was partially of Tuoba Xianbei origin; see Chen Sanping 2012, 4-38.

136 Present-day Hejian 河間 in Hebei Province; see Tan 1982a, 66. by the author or by third parties is a copyright infringement and therefore prohibited. 
ery. ${ }^{137}$ Her father was the commander-in-chief ${ }^{138}$ in Jiaozhou ${ }^{139}$ and King Dao'en of the Guiji Commandery. ${ }^{140}$ The district princess was the king's third daughter.

幼聞令淑, 早敦詩禮. 永徽中有敕, 簡宗女用適吐谷渾. 天子見縣主體德敦謹, 仁孝有聞.

As a child, she was alert and virtuous. She was familiar with the Shijing and the Liji at a young age. During the Yonghui era, ${ }^{141}$ it was ordered that all daughters of the imperial family were to be inspected, [to choose which one] should be used for being sent to the Tuyuhun. The Son of Heaven recognized the district princess's virtuous nature and prudent sincerity, her humane and loyal behavior was well known.

詔日: 會稽郡王道恩第三女可封金城縣主, 食邑四千戶。出降吐谷渾國王慕 容諾曷缽男成王忠為妻. 永徽三年四月出降, 春秋廿有二, 撫臨渾國五十余年. 上副所寄, 下安戎落, 年七十有六, 開元六年歲次壬午正月十七日薨於部落, 至七年八月十七日合葬於涼州南陽晖谷北崗, 禮也. 恐山移海變, 故勒芳銘.

The imperial decree said: “The third daughter of King Dao'en of Guiji Commandery has been invested with the title District Princess Jincheng. ${ }^{142}$ [The city she lives off] encompasses four thousand households. She will be given as wife to Zhong, King Cheng and eldest son of the king of the Tuyuhun state, Murong Nuohebo." The marriage took place in the fourth month of the third year of the Yonghui era. ${ }^{143}$ [She] was 22 years old at the time. ${ }^{144}$ She ruled the Tuyuhun state for over fifty years. She helped the higher ranks with their commitments and the lower ranks with pacifying the Rong tribe. [The district princess] passed away amid the

137 Kaihua lay in the southwest of present-day Lu'an 六安 in Anhui Province; see Tan 1982a, 27; Tan 1982b, 21. It is however never listed as a commandery.

138 This title was sometimes given as a symbolic rank to members of the imperial family who were not actively involved in military affairs; see Hucker 1985: 32, 474.

139 Present-day Hanoi in Vietnam; see Tan 1982b, 39. Probably more of a symbolic rank than an actual enfeoffment.

140 Present-day Shaoxing 紹興, Zhejiang Province; see Tan 1982b, 21, 55. Based on Hargett 2013, I read 會稽 as “Guiji” instead of “Kuaiji”.

$141650-655$.

142 Several places called Jincheng can be found in maps of the Tang realm but none of them is a district: (1) west of Yan'an 延安 in Shaanxi Province, (2) Xingping 興平, west of Xi'an in Shaanxi Province (see Tan 1982b, 40-41), and (3) Lanzhou 蘭州 in Gansu Province (see Tan 1982b, 62).

143 This corresponds to the period between the 14thday of the 5th month and the 11thday of the 6th month in 652 .

144 The date given is contradicted by her age, see discussion below. 
tribe at the age of seventy-six, on the seventeenth day of the first month in the sixth year of the Kaiyuan era, ${ }^{145}$ which was a renwu year. ${ }^{146}$

On the seventeenth day of the eighth month of the seventh year [of the Kaiyuan era] ${ }^{147}$ she received a joint burial [with her husband]. [Their tombs ${ }^{148}$ are situated] on the northern slope of Huigu [hill], which is located in Nanyang in Liangzhou. ${ }^{149}$ [The funeral was conducted] according to the rites. [We] were worried that the mountains would move and seas would change, therefore this fragrant epitaph was written to record her good deeds. ${ }^{150}$

Xia Nai states that even though the information in this inscription can be used to complement historical sources, some parts of the text appear to be flawed. ${ }^{151}$ If we try to trace the line of ancestry of District Princess Jincheng, it becomes apparent that some kind confusion or error must have occured. Xia points out that a close examination of the transmitted historical texts reveals that those named as Jincheng's ancestors in the seventh and sixth generation were probably the same person. According to the Xin Tang shu, ${ }^{152}$ Xuan Jiangong 宣簡公, who was also an ancestor in the sixth generation of Emperor Gaozong, was posthumously invested as Emperor Xuan 宣 in 674. ${ }^{153}$ The Xin Tang shu is also instructive regarding District Princess Jincheng's ancestor in the fifth generation, who is mentioned as Emperor Xian 先 of Tang in the epitaph. The text reveals that King Yi 噎, Gaozong's ancestor in the fifth generation and son of Emperor Xuan, posthumously received the title of Emperor Guang 光, and his wife was made Empress Guang Yi 光懿. ${ }^{154}$ Based on this information, Xia suggests that the abovementioned Emperor Xian was in fact Emperor Guang. ${ }^{155}$ He believes, that an

14521 st day in the 2 nd month of 718.

146 The 19th year in the 60-year cycle. This information cannot be true, as the renwu years in this time period are 682 and 742. If we look up the date indicated in the inscription, we learn that this was a wuwu 戊午 year, which is the 55 th year in the 60-year cycle.

147 4th day in the 10th month of 719 .

148 According to Xia 2002, 215, 218, Murong Zhong's tomb was located next to Jincheng's. Xia emphasizes that they were in fact not buried in the same tomb and that it was therefore technically not a joint burial. But it seems probable that the funeral rites were conducted on the same day.

149 Present-day Wuwei in Gansu; see Tan 1982b, 62. According to Xia 2002, 218, today this area is called Lamawan 刺麻灣. The tomb of Princess Honghua is located on a hill to the east.

150 A typical phrase in epitaphs, expressing the wish to record the good deeds of the deceased on a durable material like stone in order to make sure that they will survive the passage of time for generations; see also Ditter 2014, 31; Yao 2008, 90-91.

151 Xia 2002,211-213.

152 Xin Tangshu 3.71.

153 Xin Tangshu 70A.1957.

154 Xin Tangshu 3.71.

155 Xia 2002, 212. by the author or by third parties is a copyright infringement and therefore prohibited. 
error occurred during the writing and incising of the inscription, causing the character 光 to therefore be incorrectly written as 先. This suggestion solves the question of the identity of Emperor Xian.

According to the epitaph, the ancestor of District Princess Jincheng in the fourth generation was Qidou 乞豆. Little information can be found about this person. The name Qidou appears to be his personal name, but it seems rather unusual for a Chinese name. It seems possible that this was in fact a Xianbei-language name that was written in Chinese script. Relying on Pulleyblank's reconstruction of Early Middle Chinese, the name would have been read as EMC * ${ }^{\text {h }}{ }^{\mathrm{it}}$ dəw ${ }^{\mathrm{h}} .156$ The chapter “Zongshi shixi biao” 宗室世系表 (Tables of the Imperial Lineage) in the Xin Tang shu ${ }^{157}$ reveals that he was the youngest of Emperor Guang's sons and brother of $\mathrm{Li} \mathrm{Hu}$ 李虎 (died 551), who was posthumously given the title of Emperor Taizu of the Tang dynasty. ${ }^{158}$ At this point, the ancestry lines between District Princess Jincheng's family and the imperial ruling house split into two branches. Jincheng's grandfather, King Wen of Kaihua, was the great-uncle of Gaozu 高祖 (r. 618-626), the founding emperor of the Tang dynasty, and her father, King Dao'en of Guiji, was his second cousin. Her father is not mentioned in the "Zongshi shixi biao" of the Xin Tang shu.

Based on this line of ancestry we can conclude that District Princess Jincheng and the imperial family shared some common ancestors, namely the posthumously invested Emperors Xuan and Guang. She was therefore a daughter from a family with relatively high status, but her line of kinship was already somewhat removed from the ruling family. If we look at her ancestors' fiefdoms, it becomes apparent that they gradually became more distant from the political center of power. This development may also mirror the gradual decrease in importance of this family. The fact that District Princess Jincheng was a member of a branch of the family with shrinking influence might indicate that Tang considered this marriage and the diplomatic relations with the Tuyuhun at that point in time to be less significant. It seems that the Tang court did not want to offend the loyal Tuyuhun ruler Nuohebo and Princess Honghua, who both probably understood the Tang usage of marriage alliances quite well, by giving them a wife of low status. But at the same time, it seems that the marriage alliance was not important enough to choose a bride from a closer branch of the imperial clan.

156 Pulleyblank 1991. Interestingly, the second part of the name coincides with the element 豆 (dou), which appears in two Tuyuhun titles. In footnote 98, I follow Pelliot's suggestion that it was used to transcribe in Chinese script a possible Para-Mongolian suffix - $t u$, which was used to mark attributes as masculine; see Pelliot 1920,330. If this proves to be true, we could assume that the first part of the name, transcribed as 乞, was an attribute used as a personal name.

157 Xin Tangshu 70A.1957-1958.

158 Xin Tangshu 1.7. 
The Tuyuhun had, at that time, already lost some influence on the political stage, and the princess given to them was consequently of lower rank than the one previously sent to the Tuyuhun. Moreover, the respective emperor's different approach to foreign relations and personal attitude towards powers of Xianbei and Turkic origin might also have been a factor in this decision. It is well known that Emperor Taizong had sympathies for the so-called steppe culture and may have even been fluent in the Turkic language; ${ }^{159}$ perhaps he valued the marriage alliances with the other states more highly than Emperor Gaozong and granted them princesses of higher rank.

In the epitaph there is some confusion about the year of marriage of Princess Jincheng, the identity of her husband, and her age at the time. According to the inscription, she was married in 652 . The next sentence already contradicts this information by saying that Jincheng was 22 years old at that time. If we accept as correct her age at the time of her death as given in the inscription, we can deduce that she was born in the year 642. Therefore, she would have been only 10 years old at the time of her investiture as District Princess and, perhaps, her wedding. This observation leads us to reexamining the dates mentioned in this epitaph. As mentioned in the beginning of this section, Princess Honghua and Nuohebo came to the court shortly after Gaozong had ascended the throne. ${ }^{160}$ They asked for a wife for their eldest son, Sudu Momo (generally thought to be the same person as Murong Zhong, who is named as her husband in the epitaph); District Princess Jincheng was given to him as a wife, but there is no specification on the date of their marriage. Without the additional information given in the epitaph, any reader would assume that the wedding took place in the same year, but since we are told in the epitaph that she was 22 years old at the time of her marriage, we should not jump to this conclusion too quickly. Xia Nai also remarks on this inconsistency. Because of Jincheng's young age, he believes that Murong Zhong and Princess Jincheng were only promised to each other in $652 .{ }^{161}$ Moreover, we should also consider that Murong Zhong was six years younger than the princess, which means he was only four years old in 652. Xia assumes that the marriage itself took place 12 years later in 664, when Jincheng and Murong Zhong were 22 and 16 years old respectively. ${ }^{162}$ Even though this sounds like a reasonable and straightforward solution to this matter, we still should not draw conclusions based solely on their young age. If there were indeed two events in this story, an engagement and a wedding, we can reasonably hope to see a differentiation taking place in the language of the texts. The verbs to describe this matter are $q i$ 妻 (in the qusheng reading,

159 Chen Sanping 2012, 4-38.

160 Gaozong came to power in 650. This fits the date given in the epitaph, which is 652.

161 Xia 2002, 236.

162 Xia 2002,236-237. 
yielding Mandarin qi) in the Xin Tang shu, ${ }^{163}$ and chu jiang 出降 in the epitaph. ${ }^{164}$ To my knowledge, the meanings "to engage $\mathrm{X}$ to $\mathrm{Y}$ ” or "to promise $\mathrm{X}$ to $\mathrm{Y}$ as a wife" exist for neither term. It is fairly clear that they actually mean "to be married off" or "to marry off X". These verbs always involve a female person being given to her future husband as a wife.

This seemingly unsolvable problem might be connected to another issue concerning District Princess Jincheng. The identity of her husband is in fact not quite clear. Some scholars, such as Xia Nai, ${ }^{165}$ think that Sudu Momo (mentioned as her husband in the Xin Tang shu) and Murong Zhong (given as the name of her husband in the epitaph) were one and the same person. In this case, Sudu Momo would have been his name in the language spoken by the Tuyuhun ruling family, whereas Zhong would have been his Chinese name. Other researchers, such as Molè, ${ }^{166}$ point out inconsistencies in the dates given in the historical sources, in addition to those in the epitaphs. Following this line of inquiry, the Xin Tang shu mentions that Princess Honghua asked for another marriage some time after her oldest son Sudu Momo had died. District Princess Jinming was then given as a bride to Honghua's second son. ${ }^{167}$ From their epitaphs, we can learn that Princess Honghua and Murong Zhong were buried in the same month of the same year. If Murong Zhong was her firstborn son, it would have been impossible for her to go back to the court and ask for a wife for her second son. Sudu Momo can therefore not be the same person as Murong Zhong. Du ${ }^{168}$ suggests that Honghua in fact had three sons: Sudu Momo, Talu Momo 闥盧摸末, ${ }^{169}$ and Zhong, but Xia rejects this idea. However, in the epitaph for Princess Honghua, we find the name "Wanshu", who is identified as her fifth son. We therefore know that she most certainly had more than two sons and that Du's theory should at least be taken into consideration. The assumption that Sudu Momo and Murong Zhong were two different people can be corroborated by the fact that Sudu Momo's titles listed in the Xin Tang shu are different from those mentioned for Murong Zhong in his epitaph. ${ }^{170}$ What seems to be the most plausible explanation for the contradic-

163 Xin Tangshu221A.6227.

164 Xia 2002,211.

165 Xia 2002,215.

166 Molè 1970, 175-176.

167 See also section 4.3.3 on District Princess Jinming.

168 Du Guangiian 1941, 842 .

169 Again, this seems to be a Tuyuhun name, which may be reconstructed as ${ }^{*} t^{\mathrm{h}}$ at-lom $\mathrm{m}$-mat (Pulleyblank 1991, 199, 299). His Chinese name is unclear.

170 For a discussion of Murong Zhong's epitaph, see Xia 2002. Molè's (1970, 176) explanation for these inconsistencies is that there was a confusion with the names of the spouses. In her view, possible pairs are Sudu Momo + Jinming and Talu Momo (= Zhong) + Jincheng, or Talu Momo (as the oldest son) + Jinming and Sudu Momo (= Zhong) + Jincheng. In any case, Molè does not take into consideration the possibility that Princess Honghua had more than two sons. As for the contradictions between the 
tions concerning District Princess Jincheng's husband and her year of marriage is the postulation that during her lifetime she was actually married to both Sudu Momo and Murong Zhong. ${ }^{171}$ We have seen above that the Tuyuhun did sometimes follow the practice of levirate marriage. In this case, the remaining brother would have married the widow of his deceased brother. It seems possible that Princess Jincheng was given away as a bride at the age of ten to Sudu Momo. When he passed away, Princess Honghua asked for a wife for her second son, Talu Momo, who was married to District Princess Jinming (see section below). Perhaps District Princess Jincheng was remarried at the same time, this time to one of the younger sons, Murong Zhong. This marriage would then have taken place in 664, when she was 22 years old.

Overall, this inscription fits the observations we have made on Princess Honghua's epitaph very well. Again, the epitaph is in accordance with Chinese funerary practice and shows a strong adherence to the style of writing typical of Chinese epitaphs. Even though we see fewer allusions to Chinese poems or history than in Princess Honghua's epitaph, we can discern other typically Chinese elements: The inscription puts great importance on the kinship of the district princess and goes back several generations illustrating her descent and her blood relations to the Tang ruling house. Moreover, the language and style of the inscription adheres to the typical conventions of epitaphs; for example the last sentence reads: "[We] were worried that the mountains would move and seas would change, therefore this fragrant epitaph was written to record her good deeds." The Chinese influence seen in District Princess Jincheng's epitaph supports the previous observation that these epitaphs reflect the ongoing Sinicization of this branch of the Tuyuhun ruling family through repeated political intermarriage.

\subsubsection{District Princess Jinming}

The third Chinese princess to be given to the Tuyuhun was the district princess Jinming 金 明. No epitaph has been found for her and we can only rely on the records from transmitted texts. As mentioned in the previous section, she was given as a bride to Talu Momo, Nuohebo and Princess Honghua's second son. The year of their marriage is unclear; we only know that it took place some time after Nuohebo and Princess Honghua's firstborn son, Sudu

year of marriage and the age indicated, she ascribes it in her research of the dates to a mistake made by the author of the epitaph.

171 As for the question of why one name seems to be a Tuyuhun name and the other a Chinese name, we should take into consideration the media in which the names are found. The first is mentioned in a dynastic history, which might have used foreign names on purpose to underline their otherness. The second is found in an epitaph, a highly stylized form of text which belonged to the Chinese funerary tradition, a context in which it would seem only natural to use the Chinese names. 
Momo, had died. The Xin Tang shu ${ }^{172}$ tells us that Sudu Momo passed away a long time after his marriage to District Princess Jincheng. Princess Honghua then went to Changan with her second son, Talu Momo, to request a marriage for him, where he received District Princess Jinming as a wife. It appears that, after her firstborn son had died, Princess Honghua was hoping to renew the marital bond with the Tang by marrying her second son to a Chinese princess. After she had already suggested a marriage between her firstborn son Sudu Momo and a Tang princess some years earlier, she again asked for a Chinese princess, possibly with the goal in mind to keep Tang influence strong within the divided Tuyuhun elite.

After this event, a conflict broke out between the Tuyuhun and Tibet. Both wrote to the Tang court, blaming the other side for acts of aggression and asking for military assistance. The emperor refused both requests. This information leads to the conclusion that the Tuyuhun were no longer of importance to the Tang court, probably because they were too weak to be of use to them. Tibet then attacked the Tuyuhun and destroyed their troops. Nuohebo was not able to resist this attack and had to flee with Princess Honghua and his followers. ${ }^{173}$ From this point on, Tibet was in possession of Nuohebo's lands. An expedition to retake the original Tuyuhun lands was discussed at the Tang court in 669, but Gaozong decided against it because of a poor harvest and famine in the previous year. ${ }^{174}$ These events exemplify the political relevance of marriage alliances and their possible consequences. As mentioned above, Tibet probably also concluded marriage alliances with members of the Tuyuhun elite. It seems that Songtsen Gampo, the ruler of the Tibetan Kingdom, was quite unhappy about the renewed marriage alliance between the Tang and the Tuyuhun, which also implied a possible joint attack on Tibet, since he subsequently started a war against the Tuyuhun, though the strategic importance of the Tuyuhun territories was probably another reason for the Tibetan invasion of the Tuyuhun. According to Lin, the attacks started in 659 and lasted until $666 .{ }^{175}$ This leads to the conclusion that the marriage of District Princess Jinming probably took place some time between 652 and 659. No other marriage alliance between the Tang imperial family and the Tuyuhun is recorded after this incident, which is generally seen as the end of the Tuyuhun state, but, as discussed above, the descendants of Nuohebo and Princess Honghua continued to conclude marriages with Chinese clans.

172 Xin Tangshu 221A.6227.

173 Jiu Tangshu 198.5300.

174 Skaff 2012, 281.

175 Lin 2011, 229. 


\section{Conclusion}

A close look at marriage alliances with Chinese dynasties throughout the history of the Tuyuhun state shows that five Chinese princesses were given to the Tuyuhun: Princess Guangle (around 540), Princess Guanghua (596), Princess Honghua (640), District Princess Jincheng (around 652), and District Princess Jinming (date unclear, probably between 652 and 659). These marriages all took place at the height of Tuyuhun power, spanning a little over a century, and were strongly influenced by the position of the Tuyuhun kingdom and the political situation at the time. They should be understood as pragmatic reactions to the circumstances at hand, and not as adherence to a "heqin system" of foreign policy. The status of the women given to the Tuyuhun reflects the importance of the Tuyuhun state. They were girls or women from a branch of the imperial family, who were invested as princesses and then bestowed upon the Tuyuhun leader. If we compare the epitaphs written for Princess Honghua and District Princess Jincheng, we can discern a clear difference in length, content, and style. These observations clearly show a decline in status from Princess Honghua ${ }^{176}$ to District Princess Jincheng and finally District Princess Jinming, who did not even receive an epitaph, assuming one will not be found in the future. As for the princesses Guangle and Guanghua, we do not know the circumstances and places of their deaths. No tomb for them has been found. When Princess Honghua was married to the ruler Nuohebo in 640, the Tuyuhun kingdom was of crucial relevance to the Tang court. Not only were they important in securing access to the Western Regions, but their kingdom also served as a buffer between the Tang and the Tibetan Kingdom, which was growing stronger. The fact that both Tang and Tibet tried to win the Tuyuhun over shows that they were of great relevance, despite the comparatively small size of their kingdom. Further examination of Tibetan sources on the Tuyuhun kingdom and their marriage alliances with the Tibetan elite may help in creating a clearer image of the political situation of the Tuyuhun during this period. What is already apparent, however, is that the position of the Tuyuhun in the political and economic, as well as cultural world of this time period is often underestimated and deserves more scholarly attention.

This paper focused mainly on the epitaphs written for the two Chinese princesses Honghua and Jincheng. These, along with epitaphs found in tombs of other family members, reflect a certain familiarity with and closeness to Chinese culture. This observation is, however, limited to the branch of the Tuyuhun ruling house that remained loyal to the Tang court after Tibet had seized the Tuyuhun territories. The Tang loyalists surrounding Nuohebo fled to Liangzhou, present-day Wuwei, where the tombs of his family members were found.

176 At that point already carrying the title of "Grand Elder Princess Xiping". 
Since a rivalry for influence over the Tuyuhun had taken place in previous decades, it is very likely that tombs of members of the ruling house who were loyal to Tibet did not show such a close connection to Chinese culture. As mentioned in section 4.3, there are clear signs of marriages between members of the family loyal to Tibet and the Tibetan ruling house. A thorough reexamination of the available Tibetan sources and excavated tombs might help us create a more nuanced picture of the Tuyuhun elite.

It has become fairly clear that marital politics were an important tool among the Tuyuhun elite for strengthening their political bonds with their preferred side of the TangTibetan conflict (and others as well). We learn from the epitaphs that Nuohebo and his descendants actively participated in maritial politics with the Tang, not only with the imperial family but, after the demise of their state, also with other influential clans, such as the Wu clan. The epitaphs found in Wuwei also show that the majority of the male descendants of Nuohebo and Princess Honghua had Chinese wives, ${ }^{177}$ a factor which increasingly reduced the amount of Murong blood in their veins. By the time the tombs were built, the family was probably completely Sinicized. The strong adherence to Chinese culture seen in the epitaphs of each of the family members points to the symbolic value of these inscriptions and the tombs they belong to in emphasizing the family members' loyalty to the Tang in a time when their homeland was controlled by Tibet. This should be read as a sign of their political significance and not be identified as an indication of an on-going Sinicization process among the Tuyuhun population as a whole. These tombs only represent a fraction of the Tuyuhun elite. This family repeatedly intermarried with women of Han-Chinese descent, which means that after three generations, they would already have been only $25 \%$ Murong or Tuyuhun in origin, if one chooses to use this approach. ${ }^{178}$ Secondly, we have seen that marriage alliances were mainly driven by political motives. Thus, it becomes apparent that categorizations based on ethnicity were not as relevant to the marriage alliances concluded between the Tuyuhun and the Chinese as they were often made out to be, especially between Nuohebo's branch of the family and the Tang. A division according to ethnic categories, such as Han and nonHan, does not do justice to the complicated ethnic and cultural situation of the region of the world that we call - for want of a better term - China. In what way, then, is it relevant to figure out the "ethnic element" of a marriage alliance that took place in a time when ethnic identity was such a fluid concept? All these issues show that the study of the subject of marriage alliances, but also of the Tuyuhun and ethnicity in medieval China, are still in their early stages.

177 Yu 2013,97.

178 As I have elaborated on p. 2, it is doubtful if such a thing as a "Tuyuhun ethnic group" ever existed. From the very beginning, the population of the Tuyuhun state was not ethnically homogenous. 


\section{Bibliography}

Beckwith, Christoper I. Empires of the Silk Road. Princeton, Oxford: Princeton University, 2009.

Behnke Kinney, Anne. Exemplary Women of Early China. New York: Columbia University, 2014.

Bei shi 北史, by Li Yanshou 李延壽. 10 vols. Beijing: Zhonghua Shuju, 1974.

Chen Guansheng 陳觀勝 and Li Peizhu 李培荣 (eds). Zhongying fojiao cidian 中英佛教 詞典. Beijing: Foreign Language, 2005.

Chen Guying 陳鼓應 (ed.). Zhuangzi jinzhu jinyi 莊子今注今譯. Beijing: Zhonghua, 1983.

Chen, Jinhua 2002. "Śarīra and Scepter. Empress Wu's Political Use of Buddhist Relics", Journal of the International Association of Buddhist Studies 25.1-2 (2002), 33-150.

Chen Liangwei 陈良伟. Sichou zhi lu Henan dao 丝绸之路河南道. Beijing: Zhongguo shehui kexue, 2002.

Chen, Sanping. Multicultural China in the Early Middle Ages. Philadelphia: University of Pennsylvania, 2012.

Chin, Tamara T. "Defamiliarizing the Foreigner: Sima Qian's Ethnography and HanXiongnu Marriage Diplomacy", Harvard Journal of Asiatic Studies 70.2 (2010), 311-354.

De la Vaissière, Étienne. "Is There a 'Nationality of the Hephtalites?", Bulletin of the Asia Institute, New Series 17 (2003), 119-132.

Ding Fubao 丁福保 (ed.). Foxue da cidian 佛學大辭典. Shanghai: Shanghai Shudian, 1929.

Ditter, Alexei. "The Commerce of Commemoration: Commissioned Muzhiming in the Mid- to Late Tang", T'ang Studies 32 (2014), 21-46.

Drège, Jean-Pierre. "Les caractères de l'impératrice Wu Zetian dans les manuscrits de Dunhuang et Turfan”, Bulletin de l'Ecole française d'Extrême-Orient 73 (1984),339-354.

Du Guangiian 杜光簡. “Wudiyeba qindou kehan muzhi kaoshi”鳥地也拔勤五可汗墓誌 考釋, Zeshan banyuekan 責善半月刊 2.13(1941), 841-842.

Du Linyuan 杜林淵. “Cong chutu muzhi tan Tang yu Tuyuhun de heqin guanxi” 从出土 墓志谈唐与吐谷浑的和亲关系, Kaogu考古 2002.8, 74-80.

Galambos, Imre. "Medieval Ways of Character Formation in Chinese Manuscript Culture", Scripta 6 (2014), 49-73.

Hambis, Louis" Grammaire de la langue Mongole écrite: Première partie. Paris: Maisonneuve, 1946.

Hanji 漢紀, by Xun Yue 荀悅. See Wang Yunwu.

Han Lizhou 韩理洲. Xinzeng qian jia Tangwen zuozhe kao 新增千家唐文作者考. Xi'an: Sanqin, 1995.

Hansen, Valerie. The Silk Road: A New History. New York: Oxford University, 2012. 
Han shu 漢書, by Ban Gu 班固. Commentary by Yan Shigu 顏師古. 12 vols. Beijing: Zhonghua, ${ }^{3} 1975$ (1962).

Hargett, James M. “會稽. Guaiji? Guiji? Huiji? Kuaiji? Some Remarks on an Ancient Chinese Place-Name”, Sino-Platonic Papers 234 (2013), 1-32.

Holcombe, Charles. “The Xianbei in Chinese History”, Early Medieval China 19 (2013), 138.

Holmgren, Jennifer. "A Question of Strength: Military Capability and Princess-Bestowal in Imperial China's Foreign Relations (Han to Ch'ing)”, Monumenta Serica 39 (1990), 3185.

Hucker, Charles O. A Dictionary of Official Titles in Imperial China. Stanford: Standford University, 1985.

Jagchid, Sechin, and Jay van Simons. Peace, War, and Trade Along the Great Wall: NomadicChinese Interaction Through Two Millennia. Bloomington Indianapolis: Indiana University, 1989.

Jiu Tangshu 舊唐書, by Liu Xu 劉昫 et al. 16 vols. Beijing: Zhonghua, 1975.

Karlgren, Bernhard. The Book of Odes. Stockholm: The Museum of Far Eastern Antiquities, 1950.

Kradin, Nikolay N. "From Tribal Confederation to Empire: The Evolution of the Rouran Society”, Acta Orientalia Academiae Scientiarum Hungaricae 58.2 (2005), 149-169.

Li Li 黎李. “Minzu tuanjie de shizhe: Honghua gongzhu” 民族团结的使者一弘化公主, Fazhan 发展 2010.10, 32 .

Li Lianxiang 李連祥 (ed.). Tangshi changyong yuci 唐詩常用語詞. Tianjin: Baihua wenyi, 2009.

Li Longwen 李龍文 (ed.). Lanzhou beilin cang Gansu gudai beike tapian jinghua 蘭州碑林 藏甘肅古代碑刻拓片菁華. Lanzhou: Gansu renmin meishu, 2009.

Li Xueqin 李學勤 (ed.). Shangshu zhengyi 尚書正義. Shisanjing zhushu, 2. Beijing: Beijing Daxue, 1999.

Li Zhanzhong 李占忠. “Tuyuhun wanghou: Honghua gongzhu mu jiemi” 吐谷浑王后一 弘化公主墓解谜, Zhongguo tuzu 中國土族 2003.2, 40-43.

Liang shu 梁書, by Yao Silian 姚思廉. 3 vols. Beijing: Zhonghua, 1973.

Lienü Zhuan 列女傳, by Liu Xiang 劉向, see Wang Zhaoyuan.

Liexian zhuan 列仙傳, by Liu Xiang 劉向, see Wang Shumin.

Lin Guanqun 林冠群. Tangdai tufan shi yanjiu 唐代吐蕃史研究. Taibei: Lianjing, 2011.

Litvinsky, B.A. et al. History of Civilizations of Central Asia. Vol. 3, The Crossroads of Civilizations, AD 250-750. Paris: Unesco, 1996.

Lung, Rachel. Interpreters in Early Imperial China. Amsterdam: Benjamins, 2011.

Ma Changshou 馬長寿.Di yu Qiang 氏与姜. Guilin: Guangxi Shifan Daxue, 2006. 
Molè, Gabriella. The T'u-yü-hun from the Northern Wei to the Time of the Five Dynasties. Roma: Istituto Italiano per il Medio ed Estremo Oriente, 1970.

Pan, Yihong. "Marriage Alliances and Chinese Princesses in International Politics from Han through T'ang", Asia Major 10.1 (1997), 95-131 [Pan 1997a].

- Son of Heaven and Heavenly Qaghan: Sui-Tang China and its Neighbors. Bellingham: Western Washington University, 1997 [Pan 1997b].

Pelliot, Paul. "Note sur les Tou-yu-houen et les Sou-p'i”, Toung Pao, 2nd Series, 20.5 (1920), 323-331.

Pulleyblank, Edwin G. “The Consonantal System of Old Chinese, Part 2”, Asia Major 9 (1962), 206-65.

- Lexicon of Reconstructed Pronunciation: In Early Middle Chinese, Late Middle Chinese and Early Mandarin. Vancouver: University of British Columbia, 1991.

Rhie, Marylin Martin. Early Buddhist Art of China and Central Asia. Vol. 3, The Western

Ch'in in Kansu in the Sixteen Kingdoms Period and Inter-Relationships with the Buddhist Art of Gandhāra. Handbook of Oriental Studies, Section 4: China. Leiden: Brill, 2010.

Selbitschka, Armin. "Early Chinese Diplomacy: Realpolitik Versus the So-Called Tributary System”, Asia Major 28.1-2 (2015), 61-114.

Shangshu 尚書. See Li Xueqin.

Shiji 史記, by Sima Qian 司馬遷 and Sima Tan 司馬談. Commentaries by Pei Yin 裴駰, Sima Zhen 司馬貞, Zhang Shoujie 張守節. 6 vols. Beijing: Zhonghua, ${ }^{6} 1973$ (1959).

Shijing 詩經, see Wang Xiumei.

Shimunek, Andrew. Languages of Ancient Southern Mongolia and North China: A Historical-Comparative Study of the Serbi or Xianbei Branch of the Serbi-Mongolic Language Family, with an Analysis of Northeastern Forntier Chinese and Old Tibetan Phonology. Wiesbaden: Harrassowitz, 2017.

Simon, Rainald (ed. and trans.). Shijing: Das altchinesische Buch der Lieder. Ditzingen: Reclam, 2015.

Skaff, Jonathan Karam. Sui-Tang China and its Turko-Mongol Neighbors: Culture, Power and Connections, 580-800. Oxford: Oxford University, 2012.

Suishu 隋書, by Wei Zheng 魏徵 et al. 6 vols. Beijing: Zhonghua, 1973.

Tan Qixiang 谭其骧. Zhongguo lishi dituji. Vol. 4, Dong Jin, Shiliuguo, Nanbeichao shiqi 中 國歷史地圖集，第四册：東晉十六國，南北朝時期. Beijing: Zhonggue ditu, 1982 [Tan 1982a].

—.Zhongguo lishi dituji, Vol. 5: Sui, Tang, Wudai Shiguo shiqi 中國歷史地圖集, 第 五册: 隋唐五代十國時期. Beijing: Zhongguo ditu, 1982 [Tan 1982b].

Tang Huiyao 唐會要, by Wang Pu 王溥, see Yang Jialuo. by the author or by third parties is a copyright infringement and therefore prohibited. 
Thatcher, Melvin. "Marriages of the Ruling Elite in the Spring and Autumn Period", in: Watson and Buckley Ebrey 1991, 25-57.

Thomas, F.W. “Tibetan Documents Concerning Chinese Turkestan. I: The Ha-za”, The Journal of the Royal Asiatic Society of Great Britain and Ireland 1 (1927), 51-85.

Tongdian 通典, by Du You 杜佑. 5 vols. Beijing: Zhonghua, 1988.

Tremblay, Xavier. Pour une histoire de la Sérinde. Le manichéisme parmi les peuples et religions d'Asie Centrale d'après les sources primaires. Wien: Österreichische Akademie der Wissenschaften, 2001.

Vovin, Alexander. “Some Notes on the Tuyuhun (吐谷渾) Language: In the Footsteps of Paul Pelliot”, Journal of Sino-Western Communications 7.2 (2015), 157-166.

Wang Hong 王洪 and Tian Jun 田军 (eds.). Tangshi baike da cidian 唐诗百科大辞典. Beijing: Guangming ribao, 1990.

Wang Shumin 王叔岷 (ed.). Liexian zhuan jiaojian 列仙傳校箋. Beijing: Zhonghua, 2007.

Wang Xiumei 王秀梅(ed.). Shijing 詩經. Beijing: Zhonghua, 2006.

Wang Yunwu 王雲五 (ed.). Hanji 漢紀. Taibei: Taiwan shangwu, 1971.

Wang Zhaoyuan 王照圓 (ed.). Lienü Zhuan buzhu 列女傳補注. Shanghai: Huadong Shifan Daxue, 2012.

Watson, Rubie S. and Patricia Buckley Ebrey (eds.). Marriage and Inequality in Chinese Society. Berkeley: University of California, 1991.

Wei shu 魏書, by Wei Shou 魏收. 8 vols. Beijing: Zhonghua Shuju, 1974.

Williams, C.A.S. Chinese Symbolism and Art Motifs: An Alphabetical Compendium of Antique Legends and Beliefs, as Reflected in the Manners and Customs of the Chinese. Rutland: Tuttle, ${ }^{3} 1988$ (1974).

Xia Nai 夏鼎. “Wuwei Tangdai Tuyuhun Murong shi muzhi” 武威唐代吐谷浑慕容氏墓 志, in: Xia 2002: 210-251.

—.Kaoguxue lunwen ji 考古学论文集. 2 vols. Shijiazhuang: Hebei jiaoyu, 2002. .Xia Nai riji 夏鼎日记. Shanghai: Huadong Shifan Daxue, 2011.

Xin Tang shu 新唐書, by Ouyang Xiu 歐陽修 and Song Qi 宋祁. 20 vols. Beijing: Zhonghua, 1975.

Yao Meiling 姚美玲. Tangdai muzhi cihui yanjiu 唐代墓誌詞匯研究. Shanghai: Huadong Shifan Daxue, 2008.

Yamaguchi Zuihō 山口瑞鳳. Toban Ōkoku seiritsu shi no kenkyū 吐蕃王国成立史研究. Tokyo: Yiwanami, 1983.

Yang Jialuo 楊家駱 (ed.). Tang Huiyao 唐會要. 3 vols. Taibei: Shijie Shuju, 1968.

Yu Zhigang 于志刚. “Cong muzhi kan Tangdai Tuyuhun Nuohebo jiazu de Han hua” 从 墓志看唐代吐谷浑诺曷钵家族的汉化, Shangqiu Shifan Daxue xuebao 商丘师范大 学学报 29.1 (2013), 95-98. 
Zhou Weizhou 周偉洲. Tuyubun shi rumen 吐谷浑史入门. Xining: Qinghai renmin, 1988.

Tuyubun ziliao jilu 吐谷渾資料輯錄. Xining: Qinghai renmin, 1991.

Zhuangzi 莊子, see Chen Guying.

Zizhi tongjian 資治通鑒, by Sima Guang 司馬光. Commentary by Hu Sanxing 胡三省.

14 vols. Taibei: Zhongxin, 1976. 